\title{
Occupational Exposure to Gasoline in Gasoline Station Male Attendants Promote M1 Polarization in Macrophages
}

\section{Elshahat Toson}

Damietta University Faculty of Science

\section{Entsar saad}

Damietta University Faculty of Science

hadeer abd el-raouf omar ( $\square$ hadeeromar910@gmail.com )

Damietta University Faculty of Science

\section{Research Article}

Keywords: Antioxidant, Benzene, Phagocytosis, Inflammation, Pollutant

Posted Date: July 19th, 2021

DOl: https://doi.org/10.21203/rs.3.rs-689002/v1

License: (a) (i) This work is licensed under a Creative Commons Attribution 4.0 International License. Read Full License

Version of Record: A version of this preprint was published at Environmental Science and Pollution Research on August 27th, 2021. See the published version at https://doi.org/10.1007/s11356-021-160192. 


\section{Abstract}

Several studies have reported the toxicological implications of exposure of petroleum hydrocarbon fumes in animal models. There is little documentation on the effect of such exposure on oxidative stress levels and immune response. To our knowledge; no documentation of M1 polarization in macrophages in gasoline station male attendants. Therefore, this study aimed to evaluate the harmful effects of gasoline vapors in 62 of male attendants (16-70 years) compared to 29 age- and sex-matched- unexposed controls. The attendants were recruited from Damietta governorate gasoline stations.

Results, gasoline exposure induced significant increase in tumor necrosis factor- $a(T N F-a)$ level $(p<0.05)$ as well as a slight but non-significant increase in the activity of acidic mammalian chitinase (AMCase) ( $p$ $>0.05$ ). Further TNF- $\alpha$ /AMCase ratio was significantly increased $) p<0.01$ ) in sera of the attendants when compared to those of the healthy controls. Also, the total leucocytic and lymphocytic counts were significantly increased ( $p<0.01$ and $p<0.001$, respectively). On contrary, neutrophil to lymphocyte ratio $(\mathrm{NLR})$ and platelet to lymphocyte ratio (PLR) were significantly decreased $(\mathbf{p}<0.05$ and $\mathbf{p}<0.001$, respectively). In addition, significant reduction in hemoglobin $(\mathrm{Hb})$ concentration, plasma glutathione reduced form (GSH) and catalase, as well as superoxide dismutase (SOD) activities in red blood cells were observed in the exposed attendants. As a result, malondialdehyde (MDA), nitric oxide (NO) levels and NO/AMCase ratio were significantly increased $(\boldsymbol{p}<0.05)$. In conclusion, this study inferred that prolonged gasoline exposure can mediate immune activation; especially M1 macrophages polarization; possibly via oxidative stress mediated mechanism.

\section{Introduction}

Gasoline is one of the foremost environmental and occupational pollutants. It represents a true serious health problem. It constituted from several hundred of hydrocarbons and aromatic compounds; including benzene, toluene, and xylene (Adeniyi, 2014). In gasoline-filling stations, attendants may be subjected to physical, chemical and biological risks. A causative factor may be due to deficient safety and health attention. Persistence of work-associated diseases is serious problems (Aaohn, 2011). This is due to inhalation of gasoline vapors; even in minor quantities, can cause irritation to nose, difficulties in breathing and others. While if vapors directly contacted to the skin it can add more to the toxic effect of gasoline (Asefaw, 2020 and Rodamilans et al., 1996).

Exposure attendants to aromatics containing gasoline vapors commonly suffer from hematopoietic disorders (Periago and Prado, 2005). Activation of the inhaled gasoline and its reactive metabolic products results in continual formation of reactive oxygen species (ROS). The latter causes lipid peroxidation and destroys nucleic acids. Thus, genetic modifications and deteriorations in the tasks of vital enzymes and proteins are expected (Pac, 2017 and Domej, 2014).

Macrophages are terminally differentiated innate immune cells. Their surface membrane receptors and cytokines production orchestrate their role in immune system, homeostasis, initiation and propagation of inflammatory immune response, clearance of apoptotic ingredients or other cell debris. They also play a 
role in tissue remodeling (Bain and Schridde, 2018). Macrophages display different phenotypes depending on their environment. Two major phenotypic classifications of macrophages are defined. The first is the classically activated macrophages or the polarized pro-inflammatory phenotype (M1). It refers to the classical activation in response to Toll-like receptors (TLR) ligands such as lipopolysaccharide (LPS) and interferon-gamma (IFN- $\gamma$ ). The second is the alternatively activated macrophages (the polarized antiinflammatory phenotype, M2). Interleukin-6 (IL-6) and TNF-a; as pro-inflammatory cytokines stimulate M1 macrophage polarization while AMCase interleukin-4 (IL-4) and interleukin-13 (IL-13) are anti-inflammatory cytokines which stimulate M2 macrophage polarization (Vannella and Wynn, 2017).

M1 macrophage polarization induces $\mathrm{NO}$ as a pathogen cytotoxic component. Such polarization also activates adaptive immunity not only via activating antigen presenting cell $s$ but also $\mathrm{T}$ cell. On the other hand, M2 macrophages polarization mediate an anti-inflammatory mechanism; including secretion of antiinflammatory cytokines e.g. AMCase. The mechanism in this case induces resolution of inflammation and tissue repair (Delprat et al., 2020) versus that of the pro-inflammatory mechanism of M1 type.

TNF-a is a fundamental pro-inflammatory cytokine that participates in a variety of activities in the body. It is produced by several classes of leucocytes such as; macrophages, monocytes, neutrophils, and T-cells (Wu et al., 2013). TNF-a contributes in controlling cellular differentiation, proliferation, and immune response (AL-Rrubaei, 2020). TNF- $a$ also participates in prompting naïve T-lymphocytes to differentiate to T-helper1 (Th1) cells. In this regard, Th1 cells provide immunity to intracellular bacteria and viruses and others. T-helper2 (Th2) cells are involved in immunity to extracellular bacteria and parasites (Bystrom et al., 2020).

Chitin is a well-known environmental allergy component. Therefore, AMCase has attracted considerable attention. This is because the considerable increase in its expression in lungs of chitin-exposed asthmatic patients (Zhu et al., 2004 and Okawa et al., 2016). In this regard, secretory epithelial cells lining proximal and distal airways mediate such overexpression. Therefore, this enzyme is considered as the major endochitinases route in airway fluid (Van Dyken and Locksley, 2018).

The latter chitinase and chitinase-like proteins are mainly secreted by neutrophils. Alternatively; activated M2 macrophages, and epithelial cells were also considered (Ziatabar et al., 2018). Their interplays drive both inflammation and remodeling in chronic lung diseases; especially, chronic obstructive pulmonary disease (COPD) (Ashutosh and Kam, 2019). In this regard, chronic exposure of the lungs to toxic moieties and gases initiate not only a persistent natural inflammatory response but also an adaptive one in the airways of lung tissues. Thus, lung macrophages (LMs) are key players' effector cells in natural immunity as they engulf and destruct foreign identifiers. The letter functions of LMs finally initiates and propagate chronic inflammation in lungs; including, COPD (Akata et al., 2020).

If chitin exposure in the airways is the inflammatory mediator, AMCase activity can reflects not only the magnitude but also the duration of the accompanying immune responses and their consequences (Carrion, 2019). This mechanism explains the subsequent accumulations of chitin in these enzymedeficient mice; including age-related lung fibrosis. After restoring this enzyme activity, lung fibrosis will be 
ameliorated (Van Dyken, 2017) and human fibrotic lung disease can be prevented (Van Dyken and Locksley, 2018). Further, AMCase was noted to be induced during Th2 inflammation. An IL-13-dependent mechanism is a possible one (Elias, 2005). These inhibit chitin-mediated natural inflammatory responses. Also, the enzyme mediates allergen-induced chitin-free Th2 inflammation; and finally mediates IL-13 effector functions (Lee et al., 2011).

NO is a signaling molecule involved in many physiological and pathological processes. It is a powerful vasodilator with a half-life of few seconds in the blood. It regulates vast spectrum of physiological functions in vertebrates, including physiology, immunology and cardiovascular signaling molecule. Even in low concentrations, NO can regulates the physiological functions if in higher concentrations it may contribute to the pathogenic process (Uehara et al., 2015). NO is generated by phagocytes (monocytes, macrophages, and neutrophils) as part of the human immune response (Davies et al., 1997). It partially mediates macrophage cytotoxicity against microbes and tumor cells.

TNF-a could be used as a marker for M1 macrophage polarization but AMCase acts as a marker for M2. Therefore, TNF- $a$ / AMCase ratio could be used to estimate the dominance of M1 over M2 or vice versa. In healthy human mRNA for chitinase was found in lymph nodes, lung, and bone marrow. In addition, the enzyme protein is restrictedly expressed by phagocytes. In contrast, van Eijk et al. (2005) added neutrophils to be another source of such enzyme in human. Also, mRNA for murine chitotriosidase is expressed in the gastrointestinal tract, fore-stomach and in small intestine. Therefore, Kumagai et al. (2016) reported that, chitotriosidase (or related enzymes; including AMCase) is indicator for macrophagedriven inflammatory processes in various organs during the progression of phagocytic processes (Okawa, 2016).

NLR and PLR were previously known as systemic inflammatory biomarkers. They were immune responserelated indicators. Also, they are easily measured, reproducible, and inexpensive markers of subclinical inflammation. Additionally, these ratios are indicative of an impaired cell-mediated immunity which is associated with systemic inflammation (McMillan, 2009). PLR is calculated by subdividing PLT to that of Lymphocytes. Further, NLR is calculated by subdividing neutrophil to that of Lymphocytes. They are comprehensively indicated immune status change during the disease period (Guang et al., 2016).

Therefore, the objective of this study was to investigate the effects of gasoline exposure on M1 polarization in macrophages via assessment of TNF-a, AMCase and their ratios, as well as NO and it ratio with AMCase, respectively. Also, its effect on NLR and PLR, oxidative stress and hematological indices were evaluated in males occupationally exposed to gasoline fume during their work in in gasoline stations. Finally, if macrophages were M1or M2 polarized will also be investigated.

\section{Subjects And Samples}

A total of 91 human subjects from Damietta governorate were included in this study. The 62 attendants were exposed to gasoline for at least eight hours daily. Personal data of each participant were collected 
through short interviews using questionnaires mainly based on multiple-choice questions focusing on health status, smoking and getting any medications.

$5 \mathrm{ml}$ blood samples were collected. Of them $2 \mathrm{ml}$ were collected on EDTA and $3 \mathrm{ml}$ were left to clot. Sera and plasma samples were then obtained by centrifugation for 15 minutes at $4000 \mathrm{rpm}$ in each case and putted in eppindorff tubes. They either freshly used or stored at -200C until required for assays. TNF-a and catalase were assayed in plasma while AMCase, NO, SOD and TAC were assayed in blood sera. GSH, SOD and $\mathrm{CBC}$ were determined in whole blood. The lower erythrocyte layer in the EDTA tubes was used for determination of MDA.

\section{Chemicals}

TNFa- kit was obtained from Gscience (Glory science co., Ltd), Total antioxidant capacity (TAC), nitric oxide (NO), catalase, glutathione reduced form (GSH) kits were purchased from Bio diagnostic Co., Cairo, Egypt. Nitro blue tetrazolium (NBT), NADH, Phenazine methosulphate (PMS), sodium pyrophosphate were purchased from Sigma Co. (USA). Other chemicals used throughout these investigations were of the highest analytical grade.

\section{Immunochemical assays}

Human TNF-a was immune enzymatically assayed using an ELISA Kit from Gscience Company (Glory science Co., Ltd).

\section{Immunological assays}

AMCase activity was colourimetrically assayed immediately after blood collection, EDTA samples were analyzed using the fully hematological analyzer (Mindray BC2600) to estimate total leucocytes (WBCs), neutrophil and lymphocytes counts.

\section{Hematological assays}

Immediately after blood collection on EDTA, samples were analyzed using the fully hematological analyzer (Mindray BC2600) for estimating hemoglobin ( $\mathrm{Hb}$ ) content, red blood cells (RBCs) count, hematocrit (HCT)\% determination and platelets (PLT) count (Dacie, 2001).

\section{Determination of oxidative stress}

Superoxide dismutase (SOD) activities were assayed in red blood cells (RBCs) as well as sera according to the method described by Nishikimi et al. (1972). Assay of catalase (CAT) activity was done by the method described by Sinha (1972) and GSH concentration in blood by the method of Beutler et al. (1963). Lipid peroxidation was evaluated on the basis of malondialdehyde (MDA) level in RBCs by the method described by Stocks and Donnandy (1971). Total antioxidant capacity (TAC) was determined using a commercially available assay kit (Bio diagnostic Company for research reagents, Egypt) (Koracevic et al., 2001). Nitric oxide was also determined using a commercially available assay kit from Bio diagnostic Company. 


\section{Statistical analysis}

The data were expressed as mean \pm S.D and the statistical analysis were performed by using ANOVA followed by Post Hoc multiple comparison test (LSD). It is a parametric statistical analysis that compares between-and within-groups variance to measure differences between two or more groups. The value of $P \leq 0.05$ was considered as statistically significant. The data analysis was done with SPSS version 20 .

\section{Result}

The mean TNF-a level in sera of total attendants who were exposed to gasoline was $186.7 \pm 20 \mathrm{ng} / 100 \mathrm{ml}$ (Table 1).

In sera of attendants who were exposed for less than 10 years the level was $181.6 \pm 20 \mathrm{ng} / 100 \mathrm{ml}$ but in sera of those who exposed for more than 10 years the level was $191.9 \pm 18 \mathrm{ng} / 100 \mathrm{ml}$. Their values were significantly increased $(p<0.05)$ when compared to that of the healthy control $(134 \pm 19 \mathrm{ng} / 100 \mathrm{ml})$ (Fig. 3).

The mean AMCase activity in sera of total attendants who were exposed to gasoline was $20.12 \pm 1.3 \mathrm{U} / \mathrm{L}$ (Table 1).

In sera of attendants who were exposed for less than 10 years the mean AMCase activity was $19.94 \pm 0.95$ $\mathrm{U} / \mathrm{L}$. Further, the activity of this enzyme in sera of those who were exposed for more than 10 years was $20.3 \pm 1.57 \mathrm{U} / \mathrm{L}$. The latter activities were non-significant increased $(p>0.05)$ when compared to that of the healthy control (19.89 $\pm 0.84 \mathrm{U} / \mathrm{L}$; Fig. 3).

The mean total leucocytic count in blood of total attendants who were exposed to gasoline was $7.3 \pm 2.3$ $\times 10^{3} / \mathrm{L}$ (Table 1).

In blood of attendants who were exposed for less than 10 years was $7.85 \pm 2.63 \times 10^{3} / \mathrm{L}$ and for those who were exposed for more than 10 years was $7.729 \pm 2.06 \times 10^{3} / \mathrm{L}$. The difference between these two values and that of the healthy control $\left(6.26 \pm 1.7 \times 10^{3} / \mathrm{L}\right)$ were very significantly increased $(p<0.01 ;$ Fig. 1$)$.

The mean count of lymphocytes in blood of total attendants who were exposed to gasoline was $284 \pm 9$ $\mathrm{x} 10^{5} / \mu \mathrm{L}$ (Table 1).

In blood of attendants who were exposed for less than 10 years, this count was $278 \pm 12 \times 10^{5} / \mu$ l and those who were exposed for more than 10 years the mean value was $289 \pm 14 \times 10^{5} / \mu$ l. Statistically, these two mean value were extremely significantly increased $(p<0.001)$ when compared to that of the healthy control (207 $\pm 8 \times 10^{5} / \mu$ l; Fig. 2).

The mean count of neutrophil in blood of total attendants who were exposed to gasoline was $431 \pm 23$ $\times 10^{5} / \mu$ l (Table 1$)$. 
In blood of attendants who were exposed for less than 10 years, this count was $426 \pm 0.3 \times 10^{5} / \mu$ l and those who were exposed for more than 10 years the mean value was $436 \pm 0.3 \times 10^{5} / \mu \mathrm{l}$. Statistically, these two mean value were non significantly increased $(p>0.05)$ when compared to that of the healthy control (379 $\pm 26 \times 10^{5} / \mu$ l; Fig. 2).

Concerning hemoglobin level in blood of total attendants who were exposed to gasoline was $14.07 \pm 2.15$ $\mathrm{g} / \mathrm{dl}$ (Table 1).

In blood of those who were exposed for less than 10 years was $14.33 \pm 1.78 \mathrm{~g} / \mathrm{dl}$ and those who were exposed for more than 10 years was $13.63 \pm 2.8 \mathrm{~g} / \mathrm{dl}$. The difference between these two values and that of the healthy control $(14.26 \pm 1.6 \mathrm{~g} / \mathrm{dl})$ were non-significantly decreased $(P>0.05 ;$ Fig. 1$)$.

The mean red blood cells (RBCs) count in blood of total attendants who were exposed to gasoline was $5.13 \pm 0.82 \times 10^{6} /$ I (Table 1$)$.

Only who were exposed to gasoline for more than 10 years were showed a statistical very significantly decreased $4.83 \pm 0.9 \times 10^{6} / \mathrm{I}$ when compared to that of the healthy control $\left(5.25 \pm 0.7 \times 10^{6} / \mathrm{l}, \mathrm{p}<0.01 ; \mathrm{Fig} .1\right)$.

The mean platelets count in blood of total attendants who were exposed to gasoline was $264.7 \pm 75.2$ $\mathrm{x} 10^{3} / \mathrm{I}$ (Table 1).

In blood of attendants who were exposed for less than 10 years the level was $271.4 \pm 82 \times 10^{3} / \mathrm{l}$ but in blood of those who exposed for more than 10 years the level was $260.7 \pm 69.3 \times 10^{3} / \mathrm{I}$. Their values were significantly increased $(\mathbf{p}<0.05)$ when compared to that of the healthy control $\left(261.7 \pm 75.8 \times 10^{3} / \mathrm{I}\right)$ (Fig. 3). In all cases, only the absolute values of the parameters were depicted in the figures. 
Table 1

Effect of gasoline exposure on immunochemical, immunological and hematological assays in gasoline station male attendants and in healthy control

\begin{tabular}{|c|c|c|}
\hline Variables & Control $n=29$ & Total $n=62$ \\
\hline \multicolumn{3}{|l|}{ Immunochemical assay } \\
\hline \multirow[t]{2}{*}{ TNF-a (pg/ml) } & $1340 \pm 190.5$ & $1867.27 \pm 196.9$ \\
\hline & & $P<0.05$ \\
\hline \multicolumn{3}{|l|}{ Immunological assays } \\
\hline \multirow[t]{2}{*}{ AMCase (U/L) } & $19.89 \pm 0.84$ & $20.12 \pm 1.3$ \\
\hline & & $P>0.05$ \\
\hline \multirow[t]{2}{*}{ Total leucocytic count $\times 10^{3} / \mathrm{I}$} & $6.26 \pm 1.7$ & $7.3 \pm 2.3$ \\
\hline & & $P>0.05$ \\
\hline \multirow[t]{2}{*}{ lymphocytes $\times 10^{3} / \mu$ l } & $2.07 \pm 0.08$ & $2.84 \pm 0.09$ \\
\hline & & $P<0.001$ \\
\hline \multirow[t]{2}{*}{ Neutrophil $\times 10^{3} / \mu \mathrm{l}$} & $3.79 \pm 0.26$ & $4.31 \pm 0.23$ \\
\hline & & $P>0.05$ \\
\hline \multicolumn{3}{|l|}{ Hematological assays } \\
\hline \multirow[t]{2}{*}{$\mathrm{Hb}(\mathrm{g} / \mathrm{dl})$} & $14.26 \pm 1.6$ & $14.07 \pm 2.15$ \\
\hline & & $P>0.05$ \\
\hline \multirow[t]{2}{*}{$\mathrm{RBCs} \times 10^{6} / \mathrm{I}$} & $5.25 \pm 0.7$ & $5.13 \pm 0.82$ \\
\hline & & $P>0.05$ \\
\hline \multirow[t]{2}{*}{$\mathrm{PLT} \times 10^{3} / \mathrm{I}$} & $261.72 \pm 75.79$ & $264.65 \pm 75.2$ \\
\hline & & $P>0.05$ \\
\hline
\end{tabular}

The ratios of TNF-a/AMCase and NO/AMCase in gasoline station male attendants who were exposed to gasoline for less than 10 years $(9.51 \pm 0.8 \%$ and $45.97 \pm 6.6 \%$, respectively) and for those who were exposed for more than 10 years were $(9.59 \pm 1.1 \%$ and $62.04 \pm 8.05 \%$, respectively). These values were very significantly increased when compared with these corresponding ratios of the healthy control $(p<0.01$ and $\mathrm{p}<0.05$, respectively) (Table 2 , Fig. 3 )

The mean NLR in gasoline station male attendants who were exposed to gasoline for less than 10 years was $163.3 \pm 12.2 \%$ and for those who were exposed for more than 10 years was $148.2 \pm 10.5 \%$. These 
values was significantly decreased $(P<0.05)$ when compared with the corresponding ratio of the healthy control.

The mean PLR in gasoline station male attendants who were exposed to gasoline for less than 10 years was $99.1 \pm 5.8 \%$ and for those who were exposed for more than 10 years was $98.2 \pm 5.5 \%$. The latter values was extremely significantly decreased when compared with the corresponding ratio of the healthy control $(P<0.001 ;$ Table 2, Fig. 2).

Table 2

Effect of gasoline exposure on TNF-a/Acidic mammalian chitinase (AMCase), nitric oxide (NO)/AMCase, Neutrophils to lymphocytes (NLR) and Platelets to lymphocytes (PLR) ratios in gasoline stations male attendants and in healthy control.

\begin{tabular}{|lll|}
\hline Variables & Control $\mathbf{n}=\mathbf{2 9}$ & Total $\mathbf{n}=\mathbf{6 2}$ \\
\hline TNF-a/AMCase & $5.44 \pm 1.14$ & $9.5 \pm 0.6$ \\
& & $\mathrm{P}<0.05$ \\
NO/AMCase & $37.56 \pm 5.04$ & $53.92 \pm 5.3$ \\
& & $\mathrm{P} \leq 0.05$ \\
\hline NLR & $187.2 \pm 12.4$ & $155.8 \pm 8.01$ \\
& & $\mathrm{P}<0.05$ \\
\hline PLR & $128.3 \pm 6.4$ & $98.65 \pm 3.98$ \\
& & $\mathrm{P}<0.001$ \\
\hline $\begin{array}{l}\mathrm{p}==\text { the significance values when the results of the attendants were compared with those of the } \\
\text { healthy control }\end{array}$ & \\
\hline
\end{tabular}

The results of SOD in the blood of attendant and in their sera were non-significantly differing in attendants who were exposed for less or more than 10 years.

The mean plasma activity of catalase of total attendants who were exposed to gasoline was $372.5 \pm 30.9$ $\mathrm{U} / \mathrm{L}$. In plasma of those who were exposed either for less than 10 years or for more than 10 years was $265.81 \pm 40.8 \mathrm{U} / \mathrm{L}$ and $374.15 \pm 44.8 \mathrm{U} / \mathrm{L}$, respectively. The values were very significantly decreased $(\mathrm{p}<$ $0.01)$ when compared to that of the healthy control $(481.1 \pm 43.5 \mathrm{U} / \mathrm{L})$.

The mean blood level of GSH of total attendants who were exposed to gasoline was $22.76 \pm 1.6 \mathrm{mg} / \mathrm{dl}$ but in blood of those who were exposed for less than 10 years was $29.77 \pm 9.1 \mathrm{mg} / \mathrm{dl}$. But who were exposed for more than 10 years was $31.05 \pm 2.39 \mathrm{mg} / \mathrm{dl}$. Their values were extremely significantly decreased when compared to that of the healthy control $(30.76 \pm 8.6 \mathrm{mg} / \mathrm{dl}, \mathrm{p}<0.001)$.

The serum levels of NO of attendants who were exposed to gasoline for less than 10 years was $8.9 \pm$ $1.34 \mu \mathrm{mol} / \mathrm{l}$ but for more than 10 years was $12.57 \pm 1.5 \mu \mathrm{mol} / \mathrm{l}$. They were significantly increased $(p<0.05)$ when compared to those of the healthy control (10.32 $\pm 1.4 \mu \mathrm{mol} / \mathrm{I})$ (Fig. 3). 
For TAC, the difference between the two groups was not significantly.

On the other hand, the mean red blood cells levels of MDA was increased with the increase in the exposure period i.e. $7.8 \pm 0.08 \mu \mathrm{moles} / \mathrm{ml}$ packed cells $* 10^{-6}$ for attendant who were exposed for less than 10 years and $9.043 \pm 0.099 \mu$ moles $/ \mathrm{ml}$ packed cell $\mathrm{s}^{\star} 10^{-6}$ for those who were exposed for more than 10 years (Table 3) 
Table 3

Effect of gasoline exposure on antioxidants assays in gasoline station male attendants and in healthy control

\begin{tabular}{|c|c|c|c|c|}
\hline \multirow[t]{4}{*}{ Variables } & \multicolumn{2}{|l|}{$\begin{array}{l}\text { Controls } n= \\
29\end{array}$} & \multicolumn{2}{|c|}{ Exposed $n=62$} \\
\hline & & Total & Exposure & Exposure \\
\hline & & $n=62$ & $<10$ years & $\geq 10-37$ years \\
\hline & & & $\mathrm{n}=\mathbf{3 1}$ & $\mathrm{n}=31$ \\
\hline \multicolumn{5}{|l|}{ Antioxidants assays } \\
\hline $\mathrm{SOD}_{\mathrm{RBCS}}$ & $3.667 \pm 1.05$ & $3.63 \pm 1.45$ & $3.58 \pm 0.35$ & $3.65 \pm 1.2$ \\
\hline \multirow[t]{2}{*}{ (\% inhibition) } & & $\mathrm{P} 1>0.05$ & $\mathrm{P} 1>0.05$ & $\mathrm{P} 1>0.05$ \\
\hline & & & & $P 2>0.05$ \\
\hline $\mathrm{SOD}_{\text {Serum }}$ & $23.53 \pm 2.99$ & $24.6 \pm 1.88$ & $21.4 \pm 2.8$ & $28.77 \pm 3.8$ \\
\hline \multirow[t]{2}{*}{ (\% inhibition) } & & $\mathrm{P} 1>0.05$ & $\mathrm{P} 1>0.05$ & $\mathrm{P} 1>0.05$ \\
\hline & & & & $P 2>0.05$ \\
\hline Catalase & $481.1 \pm 43.5$ & $372.5 \pm 30.9$ & $\begin{array}{l}265.81 \pm \\
40.8\end{array}$ & $374.15 \pm 44.8$ \\
\hline \multirow[t]{2}{*}{$(\mathrm{U} / \mathrm{I})$} & & $\mathrm{P} 1<0.01$ & & $\mathrm{P} 1<0.01$ \\
\hline & & & $11<0.01$ & $P 2>0.05$ \\
\hline GSH-Reduced form & $30.76 \pm 8.6$ & $22.76 \pm 1.6$ & $29.77 \pm 9.1$ & $31.05 \pm 2.39$ \\
\hline \multirow[t]{2}{*}{$(\mathrm{mg} / \mathrm{dl})$} & & $P 1<0.001$ & $\mathrm{P} 1<0.001$ & $\mathrm{P} 1<0.001$ \\
\hline & & & & $P 2>0.05$ \\
\hline NO & $10.32 \pm 1.4$ & $11.6 \pm 1.04$ & $8.9 \pm 1.34$ & $12.57 \pm 1.5$ \\
\hline \multirow[t]{2}{*}{$(\mu \mathrm{M} / \mathrm{I})$} & & $\mathrm{P} 1<0.05$ & $\mathrm{P} 1<0.05$ & $\mathrm{P} 1<0.05$ \\
\hline & & & & $P 2>0.05$ \\
\hline TAC & $0.826 \pm 0.076$ & $\begin{array}{l}0.777 \pm \\
0.335\end{array}$ & $0.75 \pm 0.22$ & $0.757 \pm 0.07$ \\
\hline \multirow[t]{2}{*}{$(\mathrm{mM} / \mathrm{l})$} & & & $\mathrm{P} 1>0.05$ & $\mathrm{P} 1>0.05$ \\
\hline & & $11-0.00$ & & $P 2>0.05$ \\
\hline
\end{tabular}

$\mathrm{n}=$ number, values were expressed as mean \pm standard deviation, $\mathrm{P} 1=$ the significance values when the results of the attendants were compared with those of the healthy control, P2= the significance values when the results of the attendants who were exposed to gasoline for $\geq 10$ years were compared with those of attendants who were exposed to gasoline for $<10$ years. 


\begin{tabular}{|c|c|c|c|c|}
\hline Variables & $\begin{array}{l}\text { Controls } n= \\
29\end{array}$ & & \multicolumn{2}{|c|}{ Exposed $n=62$} \\
\hline \multirow{3}{*}{$\begin{array}{l}\text { MDA } \\
(\mu \mathrm{M} / \mathrm{ml} \text { packed cells }) \times 10^{-}\end{array}$} & \multirow[t]{3}{*}{$6.453 \pm 0.067$} & \multirow{3}{*}{$\begin{array}{l}7.794 \pm \\
0.613 \\
\text { P1 }<0.05\end{array}$} & \multirow{3}{*}{$\begin{array}{l}7.8 \pm 0.08 \\
P 1<0.05\end{array}$} & \multirow{2}{*}{$\begin{array}{l}9.043 \pm 0.099 \\
\mathrm{P} 1<0.05\end{array}$} \\
\hline & & & & \\
\hline & & & & $P 2>0.05$ \\
\hline \multicolumn{5}{|c|}{$\begin{array}{l}\mathrm{n}=\text { number, values were expressed as mean } \pm \text { standard deviation, } \mathrm{P} 1=\text { the significance values when the } \\
\text { results of the attendants were compared with those of the healthy control, } \mathrm{P} 2=\text { the significance values } \\
\text { when the results of the attendants who were exposed to gasoline for } \geq 10 \text { years were compared with } \\
\text { those of attendants who were exposed to gasoline for }<10 \text { years. }\end{array}$} \\
\hline
\end{tabular}

The mean TNF-a level in sera of attendants who have age less than 30 years was $157.4 \pm 15.7 \mathrm{ng} / 100 \mathrm{ml}$ and that of attendants having age more than 41 years was $194.6 \pm 17.5 \mathrm{ng} / 100 \mathrm{ml}$. The mean TNF-a level of those having age ranged from 30-41year was $210.8 \pm 28.8 \mathrm{ng} / 100 \mathrm{ml}$. Their values were significantly increased $(p<0.05)$ when compared to that of the healthy control $(134 \pm 19.1 \mathrm{ng} / 100 \mathrm{ml})($ Fig. 6).

The mean AMCase activity in sera of attendants who have age less than 30 years was $19.96 \pm 1.2 \mathrm{U} / \mathrm{L}$ and that of attendants having age more than 41 years was $19.99 \pm 1.1 \mathrm{U} / \mathrm{L}$. This activity of those having age ranged from 30-41year was $20.58 \pm 1.7 \mathrm{U} / \mathrm{L}$. The latter activities were non-significantly increased $(p>0.05)$ when compared to that of the healthy control (19.89 $\pm 0.8 \mathrm{U} / \mathrm{L})$ (Fig. 6).

The mean $\mathrm{Hb}$ concentration and total leucocytic count in blood of attendants who have age less than 30 years were $15.08 \pm 1.2 \mathrm{~g} / \mathrm{dl}$ and $7.515 \pm 2.5 \times 10^{3} / \mathrm{UL}$, respectively. In blood of those who have age more than 41 years were $13.3 \pm 2.7 \mathrm{~g} / \mathrm{dl}$ and $7.54 \pm 1.95 \times 10^{3} / \mathrm{UL}$, respectively but in blood of those who have age ranged from 30-41year were $13.62 \pm 2.6 \mathrm{~g} / \mathrm{dl}$ and $8.3 \pm 2.58 \times 10^{3} / \mathrm{UL}$, respectively. These values were significantly decreased $(p<0.05)$ when compared to those of the healthy control $(14.26 \pm 1.6 \mathrm{~g} / \mathrm{dl}$ and 6.26 $\pm 1.7 \times 10^{3} /$ UL, respectively) (Fig. 4).

The mean RBCs count in blood of attendants only who have age more than 41 years was $4.88 \pm 0.99$ $\mathrm{x} 10^{6} / \mathrm{UL}$ and those having age ranged from $30-41$ year was $4.845 \pm 0.9 \times 10^{6} / \mathrm{UL}$. Their values were very significantly decreased $(p<0.01)$ when compared to that of the healthy control $\left(5.3 \pm 0.7 \times 10^{6} / \mathrm{UL}\right)(\mathrm{Fig} .4)$.

The mean count of lymphocytes of attendants who have age less than 30years was $288 \pm 20 \times 10^{5} / \mu \mathrm{l}$ and those who have age more than 41 years was $277 \pm 20 \times 10^{5} / \mu l$. In blood of those who have age ranged from $30-41$ years was $287 \pm 20 \times 10^{5} / \mu \mathrm{l}$. These values were extremely significantly increased $(p<0.001)$ when compared to that of the healthy control $\left(207 \pm 10 \times 10^{5} / \mu \mathrm{l} ;\right.$ Fig. 5).

The ratio of TNF-a/AMCase in gasoline station male attendants who have age less than 30 years was $8.34 \pm 0.9 \%$ and that of attendants having age more than 41 years was $10.34 \pm 1.47 \%$. This ratio of those having age ranged from $30-41$ years was $9.77 \pm 0.9 \%$. The latter ratios were very significantly increased $(p<$ 0.01) when compared with the corresponding ratio of the healthy control $(5.44 \pm 1.14 \%)$. 
The ratio of NO/AMCase in gasoline station male attendants who have age less than 30 years was 43.04 $\pm 7.7 \%$ and those who have age more than 41 years was $59.77 \pm 9.3 \%$. This ratio of those having age ranged from $30-41$ years was $55.99 \pm 11.6 \%$. The latter ratios were very significantly increased $(P<0.05)$ when compared with the corresponding ratios of the healthy control (37.56 $\pm 5.04 \%$ ) (Fig. 6)

The mean NLR in gasoline station male attendants who have age less than 30 years was $138.9 \pm 13.9 \%$ and that of attendants having age more than 41 years was $157.9 \pm 13.9 \%$. This ratio of those having age ranged from $30-41$ years was $169.6 \pm 13.7 \%$. The latter ratios were significantly decreased $(P<0.05)$ when compared with the corresponding ratio of the healthy control $(187.2 \pm 12.4 \%)$.

The mean PLR in gasoline station male attendants who have age less than 30 years was $91.1 \pm 5.0 \%$ and those who have age more than 41 years was $102.27 \pm 7.4 \%$. This ratio of those having age ranged from $30-41$ years was $102.25 \pm 7.8 \%$. The latter ratios were extremely significantly decreased $(P<0.001)$ when compared with the corresponding ratio of the healthy control (128.3 $\pm 6.4 \%)$ (Fig. 5)

The mean plasma activities of catalase of attendants who have age less than 30 years was $280.5 \pm 48.9$ $\mathrm{U} / \mathrm{L}$ but in plasma of those who have age more than 41 years was $339.25 \pm 55 \mathrm{U} / \mathrm{L}$. In plasma of those who have age ranged from $30-41$ years was $337.37 \pm 56.9 \mathrm{U} / \mathrm{L}$. Their values were very significantly decreased $(p<0.01)$ when compared to that of the healthy control $(481.1 \pm 43.5 \mathrm{U} / \mathrm{L})$. On the other hand, the mean red blood cells levels of MDA and blood activities of SOD of attendants who have age less than 30 years were $7.355 \pm 2.9 \mu$ moles $/ \mathrm{ml}$ packed cells $* 10^{-6}$ and $3.406 \pm 1 \%$, respectively. In blood of those who having age ranged from 30-41years were $8.44 \pm 1.09 \mu$ moles $/ \mathrm{ml}$ packed cells* ${ }^{\star} 10^{-6}$ and $3.202 \pm 0.9 \%$, respectively. Further, the values in blood of those who have age more than 41 years were $8.985 \pm 1.32$ $\boldsymbol{\mu m o l e s} / \mathrm{ml}$ packed cells* $10^{-6}$ and $4.3 \pm 0.6 \%$, respectively. These values were significantly increased $(\mathrm{p} \leq$ 0.05 and $p<0.05$, respectively) when compared to these of the healthy control $(6.453 \pm 0.7 \mu \mathrm{moles} / \mathrm{ml}$ packed cells* $10^{-6}$ and $3.67 \pm 1.1 \%$, respectively, Table 4 ). 
Table 4

Effect of gasoline exposure on antioxidants assays in gasoline male station attendants depending on age

\begin{tabular}{|c|c|c|c|c|c|c|c|c|}
\hline Variables & & $\begin{array}{l}\text { GSH } \\
(\mathrm{mg} / \mathrm{dl})\end{array}$ & $\begin{array}{l}\text { MDA } \\
(\mu \mathrm{M} / \mathrm{ml} \\
\text { packed } \\
\text { cells }) \times 10-6\end{array}$ & $\begin{array}{l}\text { Catalase } \\
(\mathrm{U} / \mathrm{I})\end{array}$ & $\begin{array}{l}\text { TAC } \\
(\mathrm{mM} / \mathrm{l})\end{array}$ & $\begin{array}{l}\mathrm{NO} \\
(\mu \mathrm{M} / \mathrm{l})\end{array}$ & $\begin{array}{l}\text { SOD }_{\mathrm{RBCS}} \\
\text { (\% } \\
\text { inhibition) }\end{array}$ & $\begin{array}{l}\text { SOD }_{\text {Serum }} \\
\text { (\% } \\
\text { inhibition) }\end{array}$ \\
\hline $\begin{array}{l}\text { Control } \\
n=29\end{array}$ & & $\begin{array}{l}30.76 \\
\pm 8.59\end{array}$ & $\begin{array}{l}6.45 \pm \\
0.7\end{array}$ & $\begin{array}{l}481.1 \pm \\
43.5\end{array}$ & $\begin{array}{l}0.83 \pm \\
0.1\end{array}$ & $\begin{array}{l}10.32 \\
\pm 1.4\end{array}$ & $3.7 \pm 1.1$ & $\begin{array}{l}23.53 \pm \\
2.99\end{array}$ \\
\hline \multirow[t]{7}{*}{$\begin{array}{l}\text { Exposed } \\
n=62\end{array}$} & $\begin{array}{l}\text { Age } \\
\begin{array}{l}\text { 30years } \\
n=20\end{array}\end{array}$ & $\begin{array}{l}27.61 \\
\pm 10.2 \\
P 1> \\
0.05\end{array}$ & $\begin{array}{l}7.36 \pm \\
2.9 \mathrm{p} 1 \\
\leq 0.05\end{array}$ & $\begin{array}{l}280.5 \pm \\
48.9 \\
P 1< \\
0.01\end{array}$ & $\begin{array}{l}0.71 \pm \\
0.2 \\
\text { P1 } \\
0.05\end{array}$ & $\begin{array}{l}11.27 \\
\pm 2 \\
P 1> \\
0.05\end{array}$ & $\begin{array}{l}3.4 \pm 1 \\
\mathrm{P} 1<0.05\end{array}$ & $\begin{array}{l}21.37 \pm \\
2.9 \\
P 1>0.05\end{array}$ \\
\hline & \multirow[t]{2}{*}{$\begin{array}{l}\text { Age } \\
30-41 \\
\text { years } n \\
=21\end{array}$} & $\begin{array}{l}31.29 \\
\pm 8.13\end{array}$ & $\begin{array}{l}8.44 \pm \\
1.09\end{array}$ & $\begin{array}{l}337.4 \pm \\
56.9\end{array}$ & $\begin{array}{l}0.74 \pm \\
0.3\end{array}$ & $\begin{array}{l}9.03 \\
\pm 1.5\end{array}$ & \multirow[t]{2}{*}{$\begin{array}{l}3.2 \pm 0.9 \\
\mathrm{P} 1<0.05 \\
\mathrm{P} 2<0.05\end{array}$} & \multirow[t]{2}{*}{$\begin{array}{l}31.12 \pm 5 \\
P 1>0.05 \\
P 2>0.05\end{array}$} \\
\hline & & $\begin{array}{l}\text { P2 > } \\
0.05\end{array}$ & $\begin{array}{l}\mathrm{P} 2> \\
0.05\end{array}$ & $\begin{array}{l}\mathrm{P} 2> \\
0.05\end{array}$ & $\begin{array}{l}\text { P2 > } \\
0.05\end{array}$ & $\begin{array}{l}\text { P2 > } \\
0.05\end{array}$ & & \\
\hline & \multirow{4}{*}{$\begin{array}{l}\text { Age } \\
>41 \\
\text { years } \mathrm{n} \\
=21\end{array}$} & $\begin{array}{l}32.197 \\
\pm 3.2\end{array}$ & $\begin{array}{l}8.99 \pm \\
1.32\end{array}$ & $\begin{array}{l}339.3 \pm \\
55\end{array}$ & $\begin{array}{l}0.82 \pm \\
0.4\end{array}$ & $\begin{array}{l}11.93 \\
\pm 1.9\end{array}$ & \multirow{4}{*}{$\begin{array}{l}4.3 \pm 0.6 \\
P 1<0.05 \\
P 2<0.05 \\
P 3<0.05\end{array}$} & \multirow{2}{*}{$\begin{array}{l}22.65 \pm \\
4.1 \\
P 1>0.05\end{array}$} \\
\hline & & $\begin{array}{l}\mathrm{P} 1> \\
0.05\end{array}$ & $\begin{array}{l}\mathrm{P} 1 \leq \\
0.05\end{array}$ & $\begin{array}{l}\mathrm{P} 1< \\
0.01\end{array}$ & $\begin{array}{l}\mathrm{P} 1> \\
0.05\end{array}$ & $\begin{array}{l}\mathrm{P} 1> \\
0.05\end{array}$ & & \\
\hline & & $\begin{array}{l}\mathrm{P} 2> \\
0.05\end{array}$ & $\begin{array}{l}\mathrm{P} 2> \\
0.05\end{array}$ & $\begin{array}{l}\mathrm{P} 2> \\
0.05\end{array}$ & $\begin{array}{l}\text { P2 > } \\
0.05\end{array}$ & $\begin{array}{l}\text { P2 > } \\
0.05\end{array}$ & & P3 $>0.05$ \\
\hline & & $\begin{array}{l}\text { P3 > } \\
0.05\end{array}$ & $\begin{array}{l}\text { P3 > } \\
0.05\end{array}$ & $\begin{array}{l}\text { P3 > } \\
0.05\end{array}$ & $\begin{array}{l}\text { P3 > } \\
0.05\end{array}$ & $\begin{array}{l}\text { P3 > } \\
0.05\end{array}$ & & \\
\hline
\end{tabular}

$\mathrm{n}=$ number, values were expressed as mean \pm standard deviation, $\mathrm{p}=\mathrm{P} 1=$ the significance values when the results of the attendants were compared with those of the healthy control, $\mathrm{p} 2=$ the significance value when the attendants compared with those who have age $<30$ years, $p 3=$ the significance values when the attendants compared with those who have age from 30-41 years

\section{Discussion}

Among 150 chemicals of gasoline small amounts of benzene, toluene, xylene, and sometimes lead contains were included (Ekpenyong and Asuquo, 2017). Thus, many of the gasoline exposure harmful effects are due to its individual chemicals (Rodamilans et al., 1996). Its fumes have been considered as a major route of air pollution. The latter affect immunity as well as the functions of liver, kidneys, lungs, etc. (Asefaw et al., 2020). Therefore, its fume inhalation is one of the most important routes of absorption 
during occupational periods. The concentration of inhaled fume and length of exposure determine its toxicity (Ekpenyong and Asuquo, 2017).

Macrophages play a crucial role in immune defense, immune monitoring as well as immunomodulation which may be assessed using different immunological parameters. These include assessment of TNF-a, and interleukins (IL); including IL-10 and IL-12. These soluble components are essential part of human defense mechanisms against invaders (Hernández-Urzúa and Alvarado-Navarro, 2001); including gasoline exposure (Jabbar and Ali, 2020). These cytokines are produced by activated monocytes (Esche et al., 2000). As an effector molecule in innate immunity, Toll-like receptors are believed to play a critical role in initiating the subsequent inflammatory responses against endogenous and/or exogenous stimuli, a mechanism which is characterized by production of pro-inflammatory mediators such as TNF- a (Garantziotis et al., 2010). In this study, the level of TNF-a was increased in sera of attendants when compared to that of the control group. In 2003, Han et al. reported that, activated macrophages can defend against pathogen invasion by increasing the secretion of pro-inflammatory cytokines, nitric oxide or other interleukins. This is already the case in the present study in which NO serum level was increased in sera of gasoline stations male attendants; especially after lengthening of exposure time. To confirm, the occupational exposure to low-level of benzene and the joint action of toluene-xylene- as individual's components of gasoline (Rodamilans et al., 1996) showed to stimulate circulating monocytes immune response with subsequent elevation of serum TNF-a. The elevation of serum TNF-a level after gasoline exposure, in turn, may lead one to expect the involvement of an M1 classically activated macrophage in the immune-mediated toxicity of gasoline exposure. These results confirm those of Haro-García et al. (2012) who reported that the occupational exposure to benzene-toluene-xylene mixture (BTX) can stimulate TNF-a, IL-10 and IL-12 production by peripheral blood mononuclear cells )AL-Rrubaei et al., 2020).

The role of AMCase in pulmonary disease is somewhat controversial. Elias and coworkers, (2005) and others reported that, AMCase has an important role in the pathology of asthma by inducing neutrophil as well as eosinophil infiltration into lung tissues causing airway hyper-responsiveness (Donnelly and Barnes, 2004 and Shuhui et al., 2009). Therefore, highly expression of AMCase in OVA-sensitized mice in lung tissue of asthmatic patients was reported by Zhu et al. (2004). Further, the decrease in eosinophil and neutrophil recruitment to the lungs of OVA-sensitized mice which was ameliorated by chemical inhibition of AMCase allergic inflammation induced by Donnelly and Barnes (2004) confirm the role of AMCase in lung disorders. In contrast, Fitz and colleagues (2012) reported that, despite the absence of chitinase activity in models of pulmonary inflammation and allergic airway disease, the absence of AMCase had no significant effect on cellularity or airway responses (Fitz et al., 2012). The latter may be the case in the present study. Taken together, M1- but not M2 macrophage activation was mediated during occupational exposure to gasoline. Also, Wynn et al. (2016) found no role for AMCase in airway disease induced by house dust mite allergens, although AMCase was essential for developing a protective type II immune response to intestinal nematodes (Vannella et al., 2016). Locksley and coworkers (2017) showed that elder mice spontaneously develop pulmonary fibrosis and die earlier than (WT( wild type controls. This may be at least in part due to failure to digest environmental chitin, related fragments or any accumulated 
fragments in the lungs (Van Dyken et al., 2017); including gasoline. These investigators concluded that AMCase production by specific lung epithelial cells is important for chitin degradation in the airways. As evidenced from our results, gasoline exposure may lake these activities; confirming an M1 induced polarization of activated macrophage during gasoline exposure. To our knowledge, most of the previous investigators identified macrophages as the primary source of AMCase, whereas others identified murine and human neutrophils as a major source of this enzyme (Chang et al., 2001). Also, there is only one other paper which reported significant elevation of AMCase by neutrophils from patients with type-2 diabetes compared with that of the healthy individuals (Carrion et al., 2019).

Przysucha et al. (2020) reported that, mammals are mainly express chitinases and chitinase-like proteins which are secreted by phagocytes (mainly neutrophils and macrophages). These cells are induced at the sites of inflammation, infection and tissue remodeling. All of these lead one to suggest that, these proteins play active roles in the anti-infective defense and repair responses. However, major evidence for involvement of chitinase-like proteins in lung diseases was reported by Tabata et al. (2018) and by Patel and Goyal (2017).

M2 macrophage activation is a major and a common feature of COPD with increased YKL-40 protein levels which can reflect M2 macrophage polarization (Da Silva et al., 2008). In general, polarization occurs during the macrophage activation process and is controlled by three variables: microenvironment, cytokines and epigenetics (Mills et al., 2000).

Given together, TNF- $\mathrm{a}$ could be used as a marker for M1 and AMCase as a marker for M2. Therefore and in our opinion, the assay of TNF-a/AMCase ratio can be used to estimate the dominance of M1 over that of M2. In this regard, this ratio was found to be very significantly elevated $(p<0.01)$ in Gasoline Station male attendants when compared with the corresponding ratio of the healthy control. Such increment may lead one to suggest that M1 polarization in macrophages was the major under these research conditions. Thus, gasoline exposure may act as a stimulus for inflammation as infection, debris, or apoptotic bodies do. Therefore, the activated macrophages switch their activation to be a classical one. As before, the outcome of the classical activation will result in the involvement of pro-inflammatory mode of organ damage following gasoline exposure. These represent that such exposure may trigger other pro-inflammatory including TNF-a which is actually the case in the present.

The paradigm of the M1/M2 subtypes was suggested to a parallel that of Th1/ Th2 cells (Martinez and Gordon, 2014). Since Th1 provide immunity against intracellular bacteria and virus (Bystrom et al., 2020). Gasoline may be an alternative of them. This is because it is freely diffuse into the exposed cell, causing pro-inflammatory. The latter mediate other inflammation processing which eventually cause organ damage, including fibrosis. In addition to the production of TNF-a by the activated macrophage, (Murray et al., 2014) inducible nitric oxide synthase (iNOS) is produced with a resultant increase in NO serum level (Sica and Mantovani, 2012). Furthermore, M1 cells produce iNOS, which stimulates the production of nitric oxide (NO) (Funes et al., 2018). On other hand, the M2 subtype produces an NO inhibitor. Additionally, M1 polarization uses STAT-1 as a transcription factor. In general, the complete mechanism of macrophage polarization is not yet fully understood. Since NO mean level in sera of the exposed attendants was 
increased, one can suggest that M2 polarization was inhibited; thus, favoring M1 polarization. Also, in vitro studies on human macrophages have shown that serotonin may have an important role in this activation process (Dominguez-Soto et al., 2017). Whether, gasoline exposure can affect serotonin level or not was not yet be evaluated in this study. Also, the increment in NO/AMCase ratio, especially the blood of attendants who were long exposed, confirms M1 polarization of macrophage (Gershon and Tack, 2007 and Wu et al., 2019). The M1 and M2 pathways are antithetic: while one destroys, the other repairs and an imbalance between these pathways could lead to the appearance of autoimmune diseases, metabolic instability and even cancer (Orecchioni et al., 2019).

Previous In vitro studies indicated that phagocyte-dependent generation of $\mathrm{NO}$ at concentrations greater than 400-500 nM triggers apoptosis in nearby cells (Uehara et al., 2015). This effect may act in an in a way which is similar to specialized pro-resolving mediators to dampen and/or to reverse inflammatory responses by neutralization and speeding the clearance rate of pro-inflammatory cells from the inflamed tissues (Li et al., 2006). Thus, the over production of NO in sera of attendants may lead one to propose its involvement in cell debris clearance or damaged cell apoptosis.

Variation of both neutrophil and lymphocytes, and their ratio (NLR) comprehensively indicated immune status change (Chen and Yang, 2020). Thus, the correlations of the reduction of this ratio with length of gasoline exposure in male attendants confirm a state of immune disturbance after exposure. Thus, the elevation of leucocytic count after such exposure was the case in the present study. In this regard, Hu et al., (2020) explored the diagnostic value of PLR; as a hematological parameter, and they concluded that such parameter is a classic indicator of inflammation. These confirm other inflammatory mechanisms included herein.

Oxidative stress occurs as a consequence of the imbalance between pro-oxidants and antioxidants. This imbalance is due to excessive accumulation of reactive oxygen species (ROS) or antioxidant depletion or both with a resultant increase in cellular damages (Poljsak et al., 2013). In this regard, the levels of superoxide anion $\left(\mathrm{O}^{2-}\right)$, hydrogen peroxide, hydroxyl radical $(. \mathrm{OH})$ which may be increased as a consequence of disturbance in the antioxidant enzymes listed herein enhance a state of oxidative. Thus, inhalation of the gasoline fumes is a quite common cause of oxidant/antioxidant status disturbance with a possible involvement of lung related disease; a prerequisite for inflammation persistence. In vitro study by Domej (2014) confirms these inter-relationships. To confirm, Uzma et al. (2010) argue such imbalance to be due to enhanced benzene metabolism and formation of hydroquinone and 1, 2, 4 benzene triol. The latter help to generate ROS as well as to impair antioxidant defense system. These together induce oxidative stress as well as immune suppression (Uzma et al., 2010). Jabir et al., (2016) added that ROS are generated by the dust particles of the inhaled gasoline and by the oxidative burst of macrophages and neutrophils activated during their phagocytosis. All together mediate the persistence of inflammation among attendants.

Total antioxidant capacity (TAC) is a dynamic equilibrium affected by interactions between each serum antioxidative constituent, where antioxidants collaboration supplies human body with greater protection against free radicals than any antioxidant lonely. Thus, TAC considers the cumulative effect of all 
antioxidants present in blood and body fluids (Stocks and Donnandy, 1971). Thus, TAC cause free radicals like $\mathrm{OH}$ - radical, $\mathrm{H}_{2} \mathrm{O}_{2}, \mathrm{HOCl}$ or $\mathrm{O}^{2-}$ radical attempts to destroy any of the cellular integrity by acting on the lipid bi layer of the cellular plasma membrane this may be the case in the present study (Wu et al., 2013) with subsequent formation of MDA (Wright and Welbourne, 2002) revealed that MDA increases from the reaction between $(\mathrm{OH}$.) radicals and cellular poly unsaturated fatty acids, resulting in loss of cell. Increased oxidative stress, as well as lipid peroxidation represented by elevated levels of MDA gives an indication of cellular damage that is usually accompanied by reduction of TAC, SOD, CAT activities and GSH content (Mohammed et al., 2016). GSH helps in detoxification and protecting cells from ROS, while both SOD and CAT enzymes are supplementary in function. They are the primary antioxidant defense components that catalyze superoxide dismutation radicals $\left(\mathrm{O}^{2-}\right)$ to $\mathrm{H}_{2} \mathrm{O}_{2}$ which is then converted to $\mathrm{H}_{2} \mathrm{O}$ by CAT. The present data showed depletion of TAC, SOD, CAT and GSH but accumulation of MDA, in the lysed RBCs which mediate increased risk of RBCs oxidative damage on prolonged gasoline exposure. Further, ROS can induce direct damage in RBCs membranes due to continuous oxidative degenerations as well as biochemical, physical and structural changes during their life span with subsequent removal from circulation by reticule-endothelial cells (Pac, 2017). All together distort the oxygen transport and carrying capacity of RBCs. This mechanism may be one of the causative factors of the significant reduction in RBCs count in long lived exposed attendants. Another prospect for RBCs damage may occur indirectly through benzene, as it is one of the most important constituents of gasoline (Ali et al., 2019).

In this study, the catalase and GSH activities were very significantly decreased when compared to that of the healthy control. The MDA and NO levels were significantly increased depending on duration of exposure. The activity of SOD in RBCS was significantly changes depend on age. TAC was non-significant decreased when compared with that of the control. This study agrees with Odewabi et al. (2014) who observed elevation of MDA level and reductions in the activities of SOD and CAT among gasoline filling station attendants, and disagree with (Malini and Maithily, 2017) who observed no significant difference in SOD, TAC and MDA levels.

Cerna et al., (2007) added that, benzene affects blood production by affecting the bone marrow. Further, in Korean industries, an excessive risk of hematopoietic diseases because of relatively high past exposure to benzene. $\mathrm{CBC}$ is the main assessment of gasoline toxicity in human (Edokpolo et al., 2015). In addition, gasoline hematotoxicity extended also to leucocytes, the primary protective line from infectious agents (John and Hole, 1992). The decrease in RBCS could also be attributed to the cytotoxic effects of the various gasoline constituents. As a result, the reduction in RBCS cause hemoglobin reduction as well, which was reported herein (Festus and Fan-Osuala, 2013 and Riaz et al., 2014). The toxic components, especially those in gasoline fumes, have been reported to change blood chemistry and induce anemia by causing bone marrow hypoplasia in experimental animals (Dacie and Lewis, 2001).

In this study, $\mathrm{Hb}$ and PLT were significantly decreased when compared with the control values depending on age. These agree with Al-jadaan and Alkinany (2017) and Okonkwo et al. (2016) but disagree with Mahmood (2012). The last outher observed that most of the hematological markers are not significantly affected via exposure to petroleum products; only the number of platelets showed significant decrease

Page 18/30 
(13\%) compared to that of the controls. The induced inflammatory process due to petrol vapor exposure could significantly reduce the hematological parameters and stimulate some immune processes. It has been established that chronic exposure to benzene may damage the precursors; namely the stem cells, and stromal cells resulting in bone marrow suppression due to the presence of toxic compounds that turn to oxidative compounds and thus mediate oxidative stress (Agrawal et al., 2018).

In this study, the increase in leucocytic count, neutrophil and lymphocytes of attendants disagree with that of Jabbar and Ali, (2020) who found a significant decline in total leucocytic count. These immune cells have protective functions against the invading infectious agents as well as the invading dusts or fume that can include gasoline. Their finding suggests gasoline containing aromatic hydrocarbons to be a contributor to such significant decrease in leucocytic count and their differential types. Thus, the suppression in bone marrow function after gasoline exposure and the failure in the migration of phagocytic cells may be expected and could also reduce the number of neutrophils and monocytes in a way that could affect the immune processes of the workers. These changes may make the attendants to be more vulnerable and susceptible to various infective agents (Ray and Kolls, 2017). The exposure may also be attributed to changes in numbers of lymphocytes, peripheral blood mononuclear cells (PBMCs) and macrophages, impaired responses to mitogens, and depression of neutrophil functions. Most of these changes are reported herein in the present study. Different studies have found that exposure to benzene results in a reduction in both circulating $B$ and $T$ lymphocytes in vivo and reduction in mitogen-stimulated lymphocytes proliferation (Fayed et al., 2017). Unfortunately, differentiations between B- and Tlymphocytes were not included in this but the sums of them were included; i.e. total lymphocytes. Benzene may damage the lymphocytes producing system, which regulates and inhibit both hematopoiesis and immunity. These increase sensitivity to autoimmune development, hypersensitivity, cancer, and infectious diseases (Abou-El-wafa et al., 2015). The exposure also affects the proliferation of Th1 and Th2-mediated responses. These impair humoral immunity that produces IL-6. This stimulates the differentiation and interaction of strong antibody responses but inhibits many of the phagocytic function of the cells. However, additional and further studies are required to confirm this hypothesis (Ali et al., 2019).

Studies on experimental animals and humans have shown that many chemicals suppress the immune response, leading to increased incidence of influenza and common cold (Dacie and Lewis, 2001 and Azari, 2012).

\section{Conclusion}

In conclusion, the current study represents that gasoline, its component and their metabolites can induce oxidative stress via excessive production of reactive oxygen and reactive nitrogen species. Antioxidants; TAC and GSH reduction were reduced and oxidative stress marker; MDA was over produced. Further, the exposure mediates immune disorders. Among these disorders is M1 polarization of macrophage with subsequent over production of NO and TNF-a that mediate inflammation. Moreover, reduction in NLR and PLR were observed which further confirm immune mediated gasoline toxicity. Therefore, if the exposure to gasoline is case, antioxidants supplementation is required. 


\section{Declarations}

Acknowledgement: The authors acknowledge all volunteers of participants for achieving this work and the administrative offices of gasoline stations found around Damietta governorate which helps in this study.

Ethical approval and Consent to participate: All informed written consents were obtained from all participants. For the present study, this work was approved by faculty of science Damietta University Egypt.

Consent to publish: Not applicable.

Author Contributions: El-shahat A. Toson and Entsar A. Saad conceptualized the entire work, contributions in writing the manuscript and interpretation of data and revised the manuscript. Entsar A. Saad and Hadeer A. Omar prepared the first draft of the manuscript. All authors read and approved the final paper. Hadeer A. Omar collects data, experimental work and data analysis were done.

Funding: No funding was obtained for this study.

Competing interests: The authors declare that they have no competing interests.

Availability of data and materials: All data generated or analyzed during this study are included in this manuscript.

\section{References}

1. Aaohn GA (2011) The American Association of Occupational Health Nurses. Standers of occupational and environmental health nursing, Atlanta Int J Cancer Epidemiol, 34: 516-522.

2. Abou-ElWafa S, Albadry A, El-Gilany H, Bazeed B (2015) Some biochemical and hematological parameters among petrol station attendants: a comparative study. BioMed Research International, vol. 2015, Article ID 418724, 6 pages. https://doi.org/10.1155/2015/418724

3. Adeniyi BO (2014) Pulmonary function and symptoms among petrol pump attendants in Nigeria. Int $J$ Biol Med Res 5 (1): 3780-3784.

4. Agrawal P, Krishnan M, Dixit R (2018) Air pollution and cytokines, Journal of Medical Academics 1 (1): 43-49.Doi:10.5005/JP-JOURNALS-10070-0008

5. Akata K, Stephan F (2020) Lung Macrophage Functional Properties in Chronic Obstructive Pulmonary Disease. Int J Mol Sci 21: 853. Doi: 10.3390/ijms21030853

6. Ali T, Jabbar S, Mohammed N (2019) A comparative study of interleukin 6, inflammatory markers, ferritin, and hematological profile in rheumatoid arthritis patients with anemia of chronic disease and iron deficiency anemia, Anemia, vol. 2019, Article ID 3457347, 7 pages. https://doi.org/10.1155/2019/3457347

7. Al-jadaan SAN, Alkinany ASJ (2017) Impact of benzene exposure on lung functions of fuel stations workers in Basra city, Southren of Iraq. International Journal of Pharmaceutical Science and Health 
Care $2(7): 31-36$.

8. AL-Rrubaei H, Jawad R (2020) Tumor Necrosis Factor - a gene polymorphism in Gasoline prolonged exposure workers. International Journal of Pharmaceutical Research 12 (4): 975-2366. Doi:10.31838/ijpr/2020.12.04.130

9. Asefaw T, Wolde M, Edao A, Tsegave A, Teklu G, Tesfay F, Gebremariam G (2020) Assessment of liver and renal function tests among gasoline exposed gas station workers in Mekelle city, Tigray region. Northern Ethiopia (15)10. Doi: 10.1371/journal.pone.0239716

10. Ashutosh K., Kam Y, Zhang J (2019) Human Chitinases: Structure, Function, and Inhibitor Discovery. Advances in Experimental Medicine and Biology 1142: 230-45. https://doi.org/10.1007/978-981-137318-3-11

11. Azari MR, Konjin ZN, Zayeri F, Salehpour S, Seyedi MD (2012) Occupational exposure of petroleum depot workers to BTEX compound. Int J Occup Environ Med 3 (1): 39-44.

12. Bain CC, Schridde A (2018) Origin, Differentiation, and Function of Intestinal Macrophages. Front. Immunol 9: 2733. Doi:10.3389/fimmu.2018.02733

13. Beutler F, Duron O, Kelly MB (1963) Improved method of estimation of blood glutathione. J Lab Clin Med 61 (5): 882-8.

14. Bystrom J, Taher TE, Mageed RA (2020) Metabolic Pathways Underpinning Lymphocyte differentiation and responses in Health and Disease. Immunometabolism 2 (3): e200024. https://doi.org/10.20900/immunometab20200024

15. Carrion S, Abbondante S, Clark H, Marshall M, Mouyna I et al (2019) Aspergillus fumigatus corneal infection is regulated by chitin synthases and by neutrophil-derived acidic mammalian chitinase. European Journal of Immunology, Wiley-VCH Verlag, 49 (6): 918-927. Doi: 10.1002/eji.201847851.

16. Cerna M, Kratenova J, Zejglicova K. et al. (2007) Levels of PCDDs, PCDFs, and PCBs in the blood of the non-occupationally exposed residents living in the vicinity of a chemical plant in the Czech Republic. Chemosphere 67: 238-246.

17. Chang N-CA, Hung S-I, Hwa K-Y, Kato I, Chen J-E, Liu C-H, Chang AC (2001) A macrophage protein, Ym1, transiently expressed during inflammation is a novel mammalian lectin. J Biol Chem 276 (20): 17497-17506. Doi:10.1074/jbc.M010417200.

18. Chen T, Yang M (2020) Platelet-to-lymphocyte ratio is associated with cardiovascular disease in continuous ambulatory peritoneal dialysis patients. Internatioal Immunopharmacology 78, 106063.

19. Da Silva CA, HartI D, Liu W, Lee CG, Elias JA (2008) TLR-2 and IL-17A in Chitin-Induced macrophage activation and acute inflammation. J Immunol 181: 4279-4286.

20. Dacie JV, Lewis SM (2001) Practical Hematology 9th edition. Churchill Livingstone, London 1(2):633.

21. Davies SA, Stewart EJ, Huesmaan GR, Skaer NJ (1997) Neuropeptide stimulation of the nitric oxide signaling pathway in Drosophila melanogaster Malpighian tubules. Am J Physiol 273 (2): 823-827. Doi:10.1152/ajpregu.1997.273.2.R823

22. Delprat V, Tellier C, Demazy C et al (2020) Cycling hypoxia promotes a pro-inflammatory phenotype in macrophages via JNK/p65 signaling pathway. Sci Rep 10: 882. https://doi.org/10.1038/s41598-020- 
57677-5

23. Domej W, Oettl K, Renner W (2014) Oxidative stress and free radicals in COPD - implications and relevance for treatment. Int J Chron Obstruct Pulmon Dis 9: 1207-24. doi:10.2147/COPD.S51226

24. Dominguez-Soto A, Usategui A, Casas-Engel ML, Simon-Fuentes M, Nieto C, Cuevas VD, Vega MA, Luis Pablos J, Corbi AL (2017) Serotonin drives the acquisition of a profibrotic and anti-inflammatory gene profile through the 5-HT7R-PKA signaling axis. Sci Rep 7: 14761. Doi: https://doi.org/10.1038/s41598017-15348-y

25. Donnelly LE, Barnes P J (2004) Acidic mammalian chitinase-a potential target for asthma therapy. Trends Pharmacol Sci 25 (10): 509-511. doi: 10.1016/j.tips.2004.08.002

26. Edokpolo B, Yu Q J, Connell D (2015) Health risk assessment for exposure to benzene in petroleum refinery environments Int. J. Environ. Res. Public Health 12: 595-610.

27. Ekpenyong C, Asuquo A (2017) Recent advances in occupational and environmental health hazards of workers exposed to gasoline compounds," International Journal of Occupational Medicine and Environmental Health 30 (1): 1-26. Doi: https://doi.org/10.13075/ijomeh.1896.00800

28. Elias JA, Homer RJ, Hamid Q, Lee CG (2005) Chitinases and chitinase-like proteins in TH2 inflammation and asthma. Asthma diagnosis and treatment 116 (3): 497-500. Doi: https://doi.org/10.1016/j.jaci.2005.06.028

29. Esche C, Shurin MR, Lotze MT (2000) IL-12. Biological Therapeutics Program, University of Pittsburgh Cancer Institute, Pittsburgh, PA, USA. 18.

30. Fayed M, Aly S, Saleh S, Ebeid E, Aahmed Y (2017) Phenotype analysis of lymphocytes in workers with chronic benzene exposure. The Egyptian Journal of Haematology 42 (4): 161-168. Doi: 10.4103/1110-1067.225090

31. Festus O O, Fan-Osuala C (2013) Plasma renal functions amongst'petrol station'attendants in Owerri, south-east Nigeria. Int J Commun Res 2 (2): 34-38.

32. Fitz LJ, Declercq C, Brooks J, Kuang W, Bates B, Demers D, Winkler A et al (2012) Acidic mammalian chitinase is not a critical target for allergic airway disease. Am J Respir Cell Mol Biol 46 (1): 71-79. doi: $10.1165 / \mathrm{rcmb} .2011-00950 \mathrm{C}$

33. Funes SC, Rios M, Escobar-Vera J, Kalergis AM (2018) Implications of macrophage polarization in autoimmunity. Immunology 154: 186-195. https://doi.org/10.1111/imm.12910

34. Garantziotis S, Li Z, Potts EN, Lindsey JY, Stober VP, Polosukhin VV, Blackwell TS, Schwartz DA, Foster WM, Hollingsworth JW (2010) TLR4 is necessary for hyaluronan-mediated airway hyper responsiveness after ozone inhalation. Am J Respir Crit Care Med 181 (7): 666-675. Doi: 10.1164/rccm.200903-0381oc

35. Gershon MD, Tack J (2007) The serotonin signaling system: From basic understanding to drug development for functional GI disorders. Gastroenterology 132: 397-414. https://doi.org/10.1053/j.gastro.2006.11.002

36. Guang SHI, Zheng P, Fucheng HE, Wang W, Ming L (2016) Platelet to- Lymphocyte Ratio, Superior to Neutrophil-to-Lymphocyte Ratio, Correlates with Hepatitis C Virus (HCV) Infection, International 
Journal of Infectious Diseases, accepted manuscript.

37. Han SB, Yoon YD, Ahn YJ, Lee HS, Lee CW, Yoon WK, Park SK., Kim HM (2003) Toll-like receptormediated activation of $B$ cells and macrophages by polysaccharide isolated from cell culture of Acanthopanax senticosus. International Immuno pharmacology 3 (9): 1301-1312. Doi: 10.1016/S1567-5769(03)00118-8

38. Haro-García LC, Juárez-Pérez CA, Aguilar-Madrid G, Vélez-Zamora NM, Muñoz-Navarro S, ChacónSalinas R, González-Bonilla CR, Iturbe-Haro CR, Estrada-García I, Borja-Aburto VH (2012) Production of IL-10, TNF and IL12 by peripheral blood mononuclear cells in mexican workers exposed to a mixture of benzene-toluene-xylene. Archives of Medical Research 43 (1): 51-57. Doi: 10.1016/j.arcmed.2012.01.008

39. Hernández-Urzúa MA, Alvarado-Navarro A (2001) Interleucinas e inmunidad innata. Rev Biomed 12 (4): 272-280. Doi:10.32776/revbiomed.v12i4.286

40. Hu Z, Tan S, Chen S, Qin S, Chen H, Qin S, Huang Z, Zhou F, Qin X (2020) Diagnostic value of hematological parameters platelet to lymphocyte ratio and hemoglobin to platelet ratio in patients with colon cancer. Clinica Acta, accepted manuscript.

41. Jabbar A S, Ali E T (2020) Impact of Petroleum Exposure on Some Hematological Indices, Interleukin6 , and Inflammatory Markers of Workers at Petroleum Stations in Basra City. Journal of Environmental and Public Health 39: 379-403.

42. Jabir MS, Khalil OA, Taqi Z J, Hussain HA (2016) Biochemical Changes in Hepatic Function of Petrol Station Attendants in Basrah. Journal of Al-Nahrain University, 19 (4): 135-138.

Doi:10.22401/JNUS.19.4.18

43. John W, Hole Jr (1992) Essentials of human anatomy and physiology (4th Ed), USA: Wm. C. Brown Publisher.

44. Koracevic $D$, koraceivic $\mathrm{G}$ et al (2001) Method for the measurement of antioxidant activity in human fluids J Clin Pathol 54: 356-361. Doi: 10.1136/jcp.54.5.356

45. Kumagai E, Mano Y, Yoshio S, Shoji H, Sugiyama M, Korenaga M, Ishida T, Arai T, Itokawa N, Atsukawa M, Hyogo H, Chayama K., Ohashi T, Ito K., Yoneda M, Kawaguchi T, Torimura T, Nozaki Y, Watanabe S, Mizokami M, Kanto T (2016) Serum YKL-40 as a marker of liver fibrosis in patients with non-alcoholic fatty liver disease. Scientific Reports 6: 35282. Doi: 10.1038/srep35282

46. Lee CG, Da Silva CA, Dela Cruz CS, Ahangari F, Ma B, Kang MJ, He CH, Takyar S, Elias JA (2011) Role of chitin and chitinase/chitinase-like proteins in inflammation, tissue remodeling, and injury. Annu Rev Physiol., 73: 479-501. Doi: 10.1146/annurev-physiol-012110-142250

47. Li C, Pang Bo, Kiziltepe T, Trudel L J, Engelward B P, Dedon P C, Wogan G N (2006) Threshold Effects of Nitric Oxide-Induced Toxicity and Cellular Responses in Wild-Type and p53-Null Human Lymphoblastoid Cells. Chemical Research in Toxicology 19 (3): 399-406.

48. Mahmood NMA (2012) Relationship between exposure to petrol products and the trace metal status, liver toxicity and hematological markers in gasoline filling workers in Sulaimani city. J Environ Occup Sci 1(1): 6-11. 
49. Malini S S N, Maithily K (2017) Analysis of Oxidative Stress in Chronic Exposure to Petroleum Hydrocarbons in Karnataka, India. Asia Pac J Med Toxicol 6: 6-11.

50. Martinez FO, Gordon S (2014) The M1 and M2 paradigm of macrophage activation: Time for reassessment. F1000 Prime Rep 6: 13. https://doi.org/10.12703/P6-13

51. McMillan DC (2009) Systemic inflammation, nutritional status and survival in patients with cancer. Curr Opin Clin Nutr Metab Care 12: 223-26.

52. Mills CD, Kincaid K., Alt JM, Heilman MJ, Hill AM (2000) M-1/ M-2 macrophages and the Th1/Th2 paradigm. J Immunol 164: 6166-6173. Doi: https://doi.org/10.4049/jimmunol.164.12.6166

53. Mohammed B, AL-Thwani A, Kannan R (2016) Investigate the joint effect of tobacco exposure and alteration of TNF-a CD8, MDA and GSH levels in blood of Iraqi smokers. New York Science J 9 (7): 1116. Doi:10.7537/marsnys090716.03

54. Murray PJ, Allen JE, Biswas SK, Fisher EA, Gilroy DW, Goerdt S, Gordon S, Hamilton JA, Ivashkiv LB, Lawrence $T$ et al (2014) Macrophage activation and polarization: Nomenclature and experimental guidelines. Immunity 41: 14-20. Doi: https://doi.org/10.1016/j.immuni.2014.06.008

55. Nishikimi M, Roa NA, Yogi K. (1972) The occurrence of superoxide anion in the reaction of reduced phenazine methosulfate and molecular oxygen. Biochem Biophy Res Commun 46 (2): 849-54. Doi: 10.1016/s0006-291x (72)80218-3

56. Odewabi AO, Ogundahunsi OA, Oyalowo M (2014) Effect of exposure to petroleum fumes on plasma antioxidant defense system in petrol attendants. Br J Pharmacol Toxicol 5 (2): 83-87. http://dx.doi.org/10.19026/bjpt.5.5461

57. Okawa K, Ohno M, Kashimura A, Kimura M, Kobayashi Y, Sakaguchi M, Sugahara Y, Kamaya M, Kino Y, Bauer P, Oyama F (2016) Loss and Gain of Human Acidic Mammalian Chitinase Activity by Nonsynonymous SNPs. Mol Biol Evol 33 (12): 3183-3193. Doi:10.1093/molbev/msw198

58. Okonkwo C, Ehileboh A, Nwobodo E, Dike C (2016) The effects of acute gasoline vapour inhalation on some haematological indices of albino wistar rats. Journal of acute disease 5(2): 123-125.

59. Orecchioni M, Ghosheh Y, Pramod AB, Ley K. (2019) Macrophage Polarization: Different Gene Signatures in M1 (LPS+) vs. Classically and M2 (LPS) vs. Alternatively Activated Macrophages. Front. Immunol 10: 1084. Doi: 10.3389/fimmu.2019.01084

60. Pac J (2017) Analysis of Oxidative Stress in Chronic Exposure to Petroleum Hydrocarbons in Karnataka, India Med Toxicol 6: 6-11. Doi: 10.22038/APJMT.2017.8471

61. Patel S, Goyal A (2017) Chitin and chitinase: Role in pathogenicity, allergenicity and health. Int J Biol Macromol 97: 331-338. Doi:10.1016/j.ijbiomac.2017.01.042

62. Periago J, Prado C (2005) Evolution of occupational exposure to environmental levels of aromatic hydrocarbons in service stations, Ann Occup Hyg 49 (3): 233-240. Doi: 10.1093/annhyg/meh083

63. Poljsak B, Šuput D, Milisav I (2013) Achieving the Balance between ROS and Antioxidants: When to Use the Synthetic Antioxidants. Oxid Med Cell Longev 2013 (1): 956792-11. doi:

$10.1155 / 2013 / 956792$ 
64. Przysucha N, Górska K, Krenke R (2020) Chitinases and Chitinase-Like Proteins in Obstructive Lung Diseases - Current Concepts and Potential Applications, International Journal of Chronic Obstructive Pulmonary Disease 15: 885-899. DOI: https://doi.org/10.2147/COPD.S236640

65. Ray A, Kolls JK (2017) Neutrophilic inflammation in asthma and association with disease severity. Trends Immunol 38 (12): 942-954.

66. Riaz MA, ljaz B, Riaz A (2014) Overview of occupational exposure to petroleum derivatives and risk of anemia in petrol station workers. Greener J Environ Manage Public Saf 3 (1): 21-25.

67. Rodamilans M, Torra M, Corbella J, Lopez B, Sanchez C, Mazzara R (1996) Effect of the reduction of petrol lead on blood lead levels of the population of Barcelona (Spain). Bull Environ ContamToxicol 56:717-721.

68. Shuhui L, Mok K, Wong S (2009) Role of mammalian chitinases in asthma. Int Arch Allergy Immunol 149: 369-377. https://doi.org/10.1159/000205583

69. Sica A, Mantovani A (2012) Macrophage plasticity and polarization: In vivo veritas. J Clin Investig 122 (3): 787-795. https://doi.org/10.1172/JCl59643

70. Sinha AK. (1972) Colorimetric assay of catalase. Anal biochem 47 (2): 389-394. doi: 10.1016/00032697(72)90132-7.

71. Stocks J, Donnandy T (1971) The autoxidation of human red cell lipids induced by hydrogen peroxide. Br J Haematol 20 (1): 95-111. Doi: 10.1111/j.1365-2141.1971.tb00790.x

72. Tabata E, Kashimura A, Kikuchi A et al (2018) Chitin digestibility is dependent on feeding behaviors, which determine acidic chitinase mRNA levels in mammalian and poultry stomachs. Sci Rep 8 (1):1461. Doi: 10.1038/s41598-018-19940-8

73. Uehara EU, Shida Bde S, deBrito CA (2015) Role of nitric oxide in immune responses against viruses: beyond microbicidal activity. Inflammation Research 64 (11): 845-52. Doi: 10.1007/s00011-0150857-2

74. Uzma N, Kumar BS, Hazari MA (2010) Exposure to benzene induces oxidative stress, alters the immune response and expression of p53 in gasoline filling workers., US National Library of Medicine National Institutes of Health 53(12): 1264-70.

75. Van Dyken S J, Locksley R M (2018) Chitins and Chitinase Activity in Airway Diseases. J Allergy Clin Immunol 142 (2): 364-369. Doi:10.1016/j.jaci.2018.06.017

76. Van Dyken SJ, Liang HE, Naikawadi RP, Woodruff PG, Wolters PJ, Erle DJ, Locksley RM (2017) Spontaneous Chitin Accumulation in Airways and Age-Related Fibrotic Lung Disease. Cell 169 (13): 497-509. Doi: https://doi.org/10.1016/j.cell.2017.03.044

77. Van Eijk M, van Roomen CP, Renkema GH et al (2005) Characterization of human phagocyte-derived chitotriosidase and a component of innate immunity. Int Immunol 17 (11): 1505-1512. Doi:10.1093/intimm/dxh328

78. Vannella K M, Ramalingam T R, Hart K. M, de Queiroz Prado R, Sciurba J, Barron L, Borthwick L A, Smith A D, Mentink-Kane M, White S, Thompson R W, Cheever A W, Bock K., Moore I, Fitz L J, Urban J F, 
Jr and Wynn T A (2016) Acidic chitinase primes the protective immune response to gastrointestinal nematodes. Nat Immunol 17: 538-544.

79. Vannella K.M, Wynn TA (2017) Mechanisms of Organ Injury and Repair by Macrophages. Annu Rev Physiol 79: 593-617. https://doi.org/10.1111/imm.12910

80. Wright DA, Welbourne P (2002) Environmental Toxicology. Cambridge University Press, Cambridge.

81. Wu H, Denna TH, Storkersen JN, Gerriets VA (2019) Beyond a neurotransmitter: The role of serotonin in inflammation and immunity. Pharmacol Res 140: 100-114.

https://doi.org/10.1016/j.phrs.2018.06.015

82. Wu JQ, Kosten TR, Zhang Prog XY (2013) Free radicals, antioxidant defense systems and schizophrenia. Neuro psycho pharmacol Biol Psychiatry 46: 200-206. Doi:

10.1016/j.pnpbp.2013.02.015

83. Zhu Z, Zheng T, Homer RJ et al (2004) Acidic mammalian chitinase in asthmatic Th2 inflammation and IL-13 pathway activation. Science, 304 (5677): 1678-1682. Doi: 10.1126/ science.1095336

84. Ziatabar S, Zepf J, Rich S, Danielson BT, Bollyky PI, Stern R (2018) Chitin, chitinases, and chitin lectins: emerging roles in human pathophysiology 25 (4): 253-262. Doi: 10.1016/j.pathophys.2018.02.005

\section{Figures}

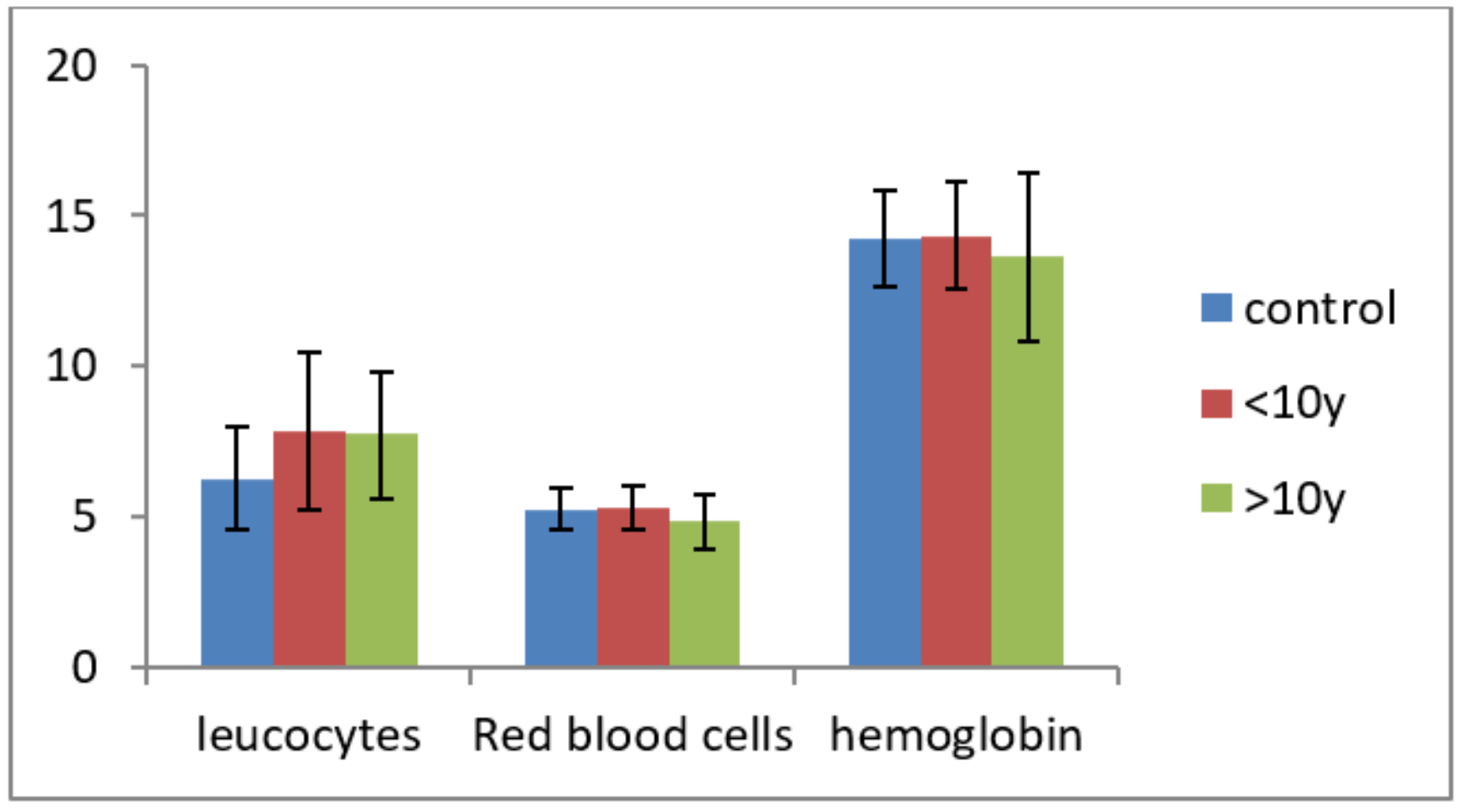

\section{Figure 1}

Effect of gasoline exposure on leucocytes, red blood cells and hemoglobin values in gasoline station male attendants who were exposed for less or more than 10 years $(<10 y,>10 y)$ and in healthy controls 


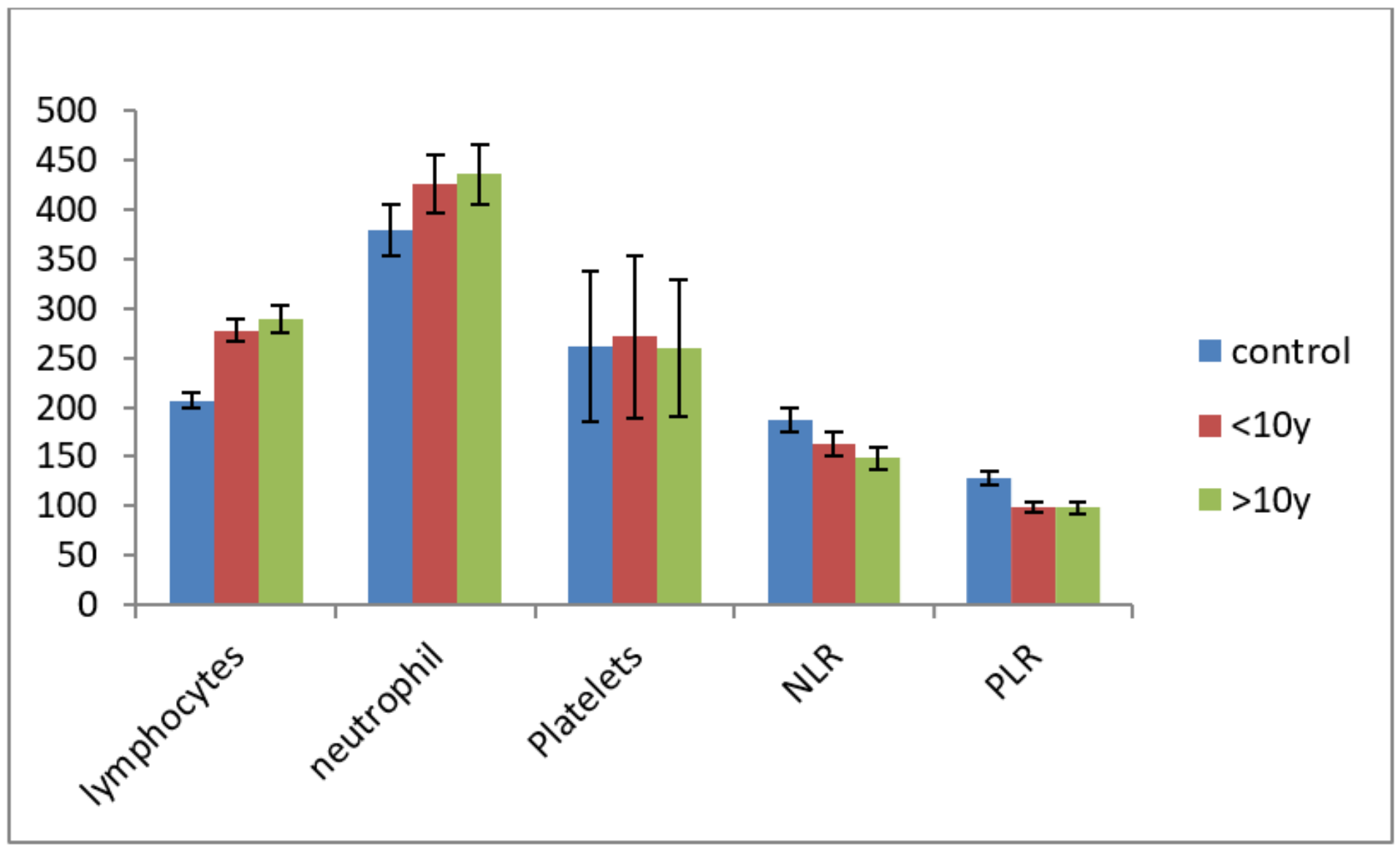

Figure 2

Effect of gasoline exposure on lymphocytes, neutrophil, platelets and their ratios $s$ in gasoline station male attendants who were exposed for less or more than 10 years $(<10 y,>10 y)$ and in healthy controls 


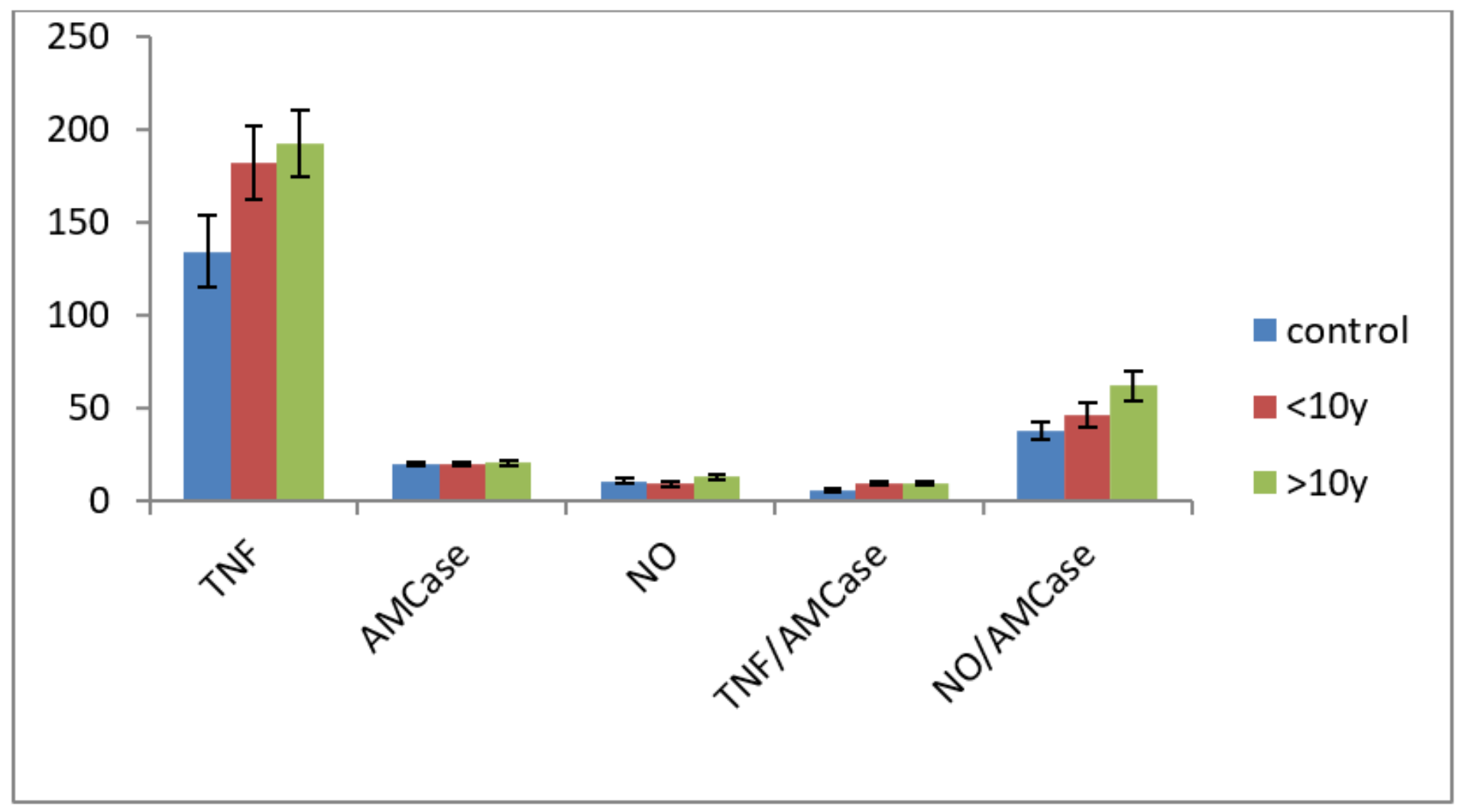

Figure 3

Effect of gasoline exposure on TNF, AMCase, NO values and on their ratios in gasoline station male attendants who were exposed for less or more than 10 years $(<10 y,>10 y)$ and in healthy controls

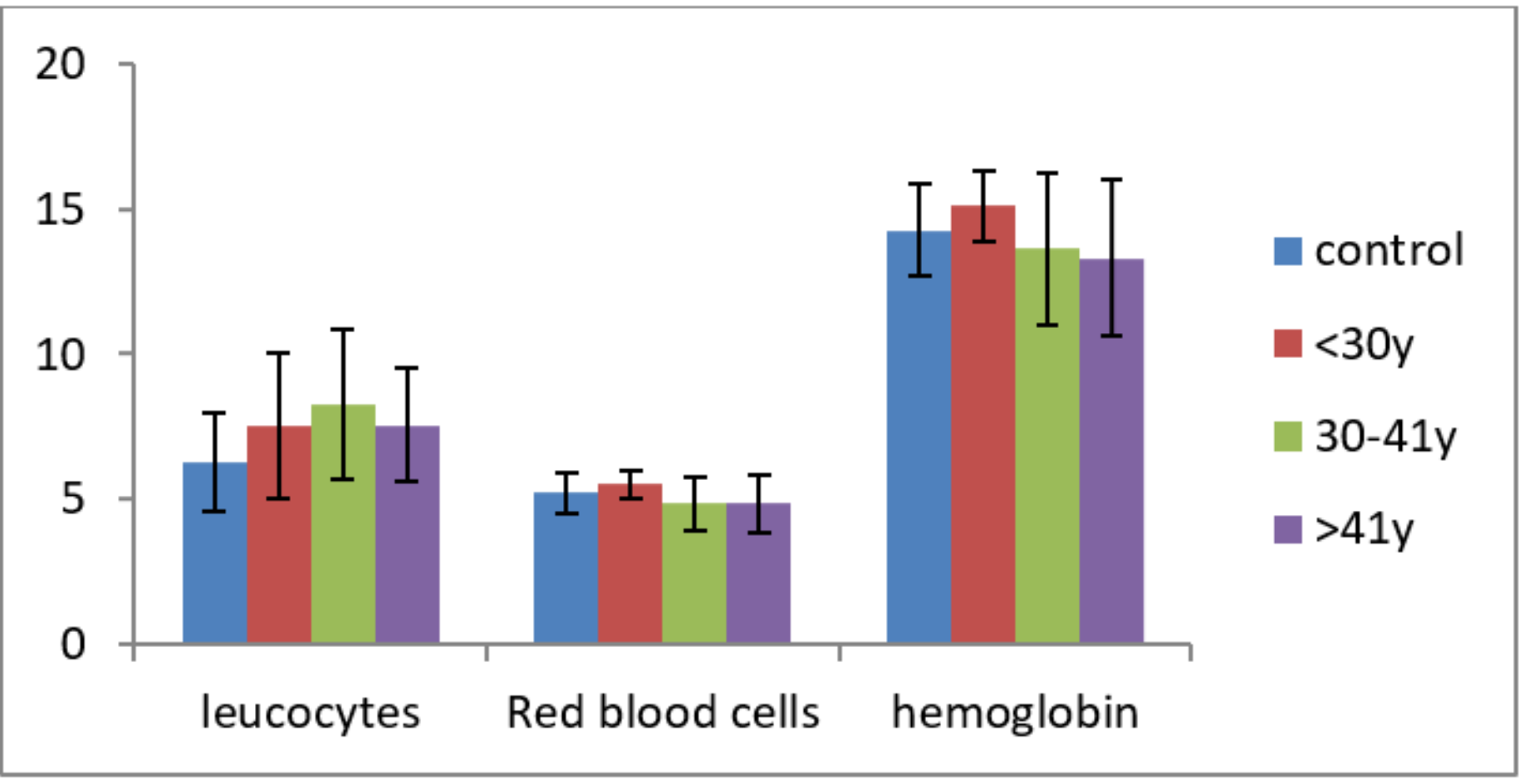

Figure 4 
Age-mediated effect of gasoline exposure on leucocytes, red blood cells and hemoglobin in gasoline male station attendants and in healthy control

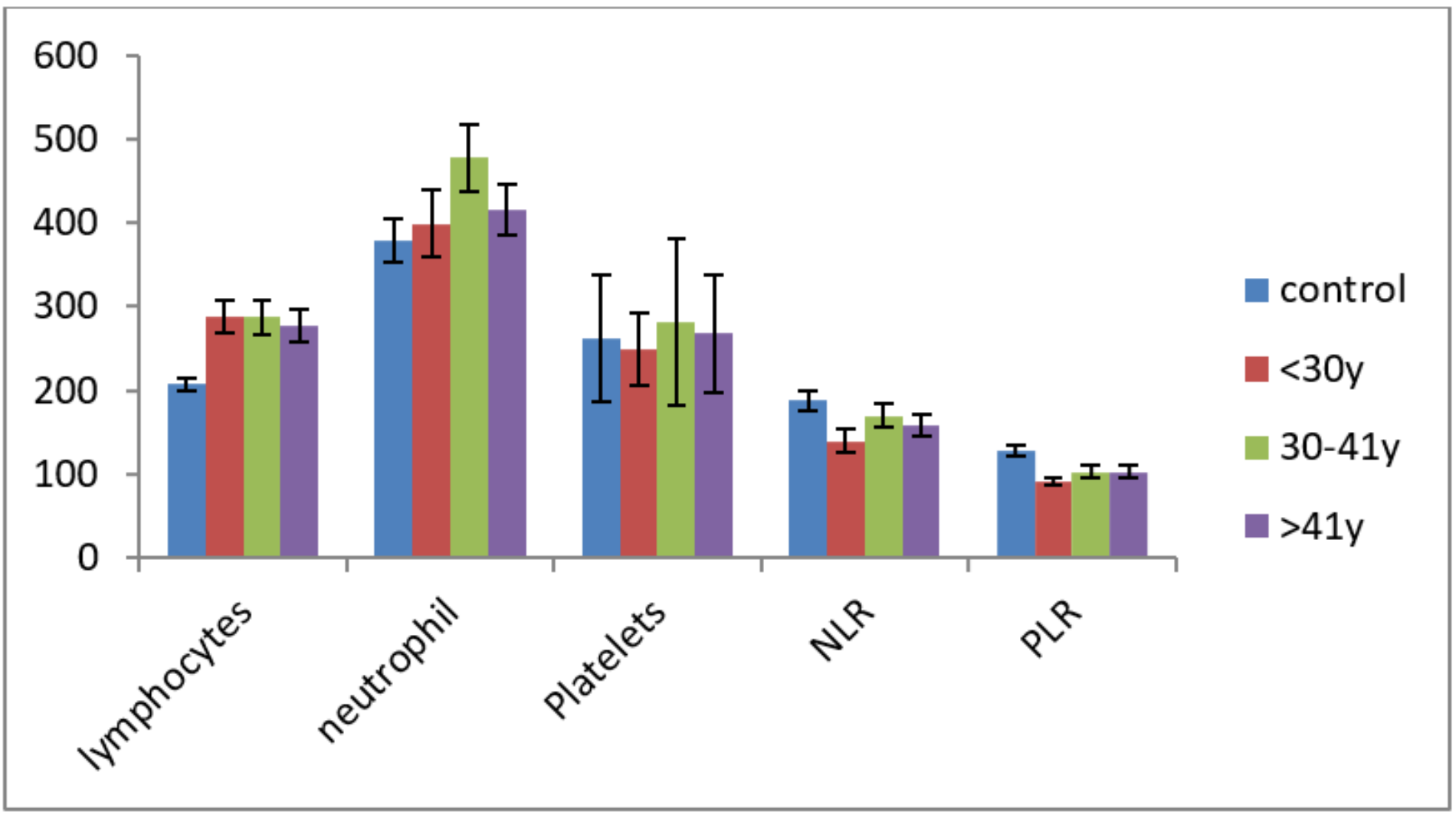

Figure 5

Age-mediated effect of gasoline exposure on lymphocytes, neutrophils, platelets and their ratios in gasoline male station attendants and in healthy control 


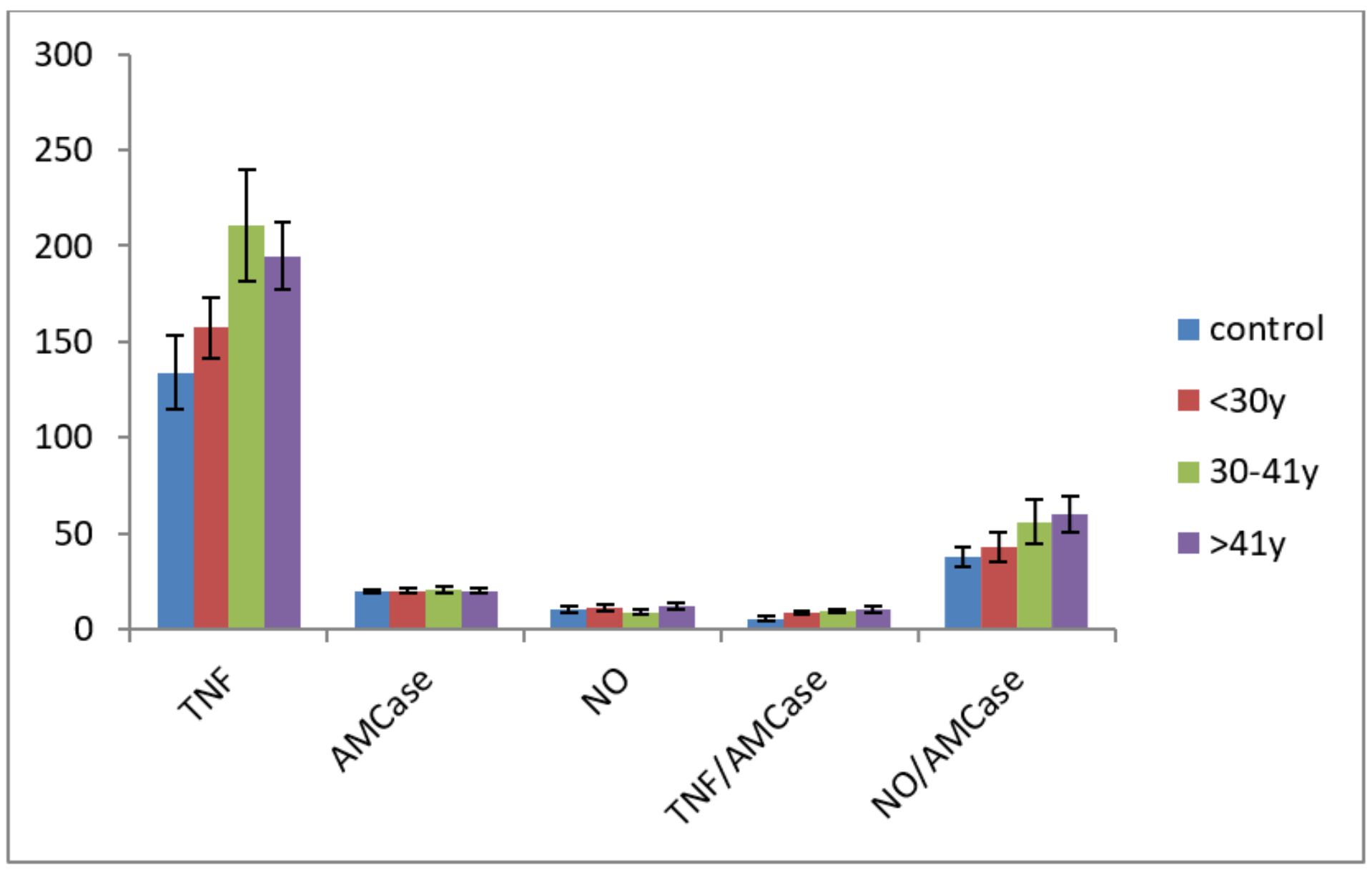

Figure 6

Age-mediated effect of gasoline exposure on TNF, AMCase, NO and their ratios of male in gasoline station attendants and in healthy control 